\title{
Discours
}

Revue de linguistique, psycholinguistique et

informatique. A journal of linguistics, psycholinguistics and computational linguistics

$4 \mid 2009$

Linearization and Segmentation in Discourse

\section{Another('s) perspective on subjectivity in causal connectives: a usage-based analysis of volitional causal relations}

Ninke Stukker and Ted Sanders

(2) OpenEdition

Journals

Electronic version

URL: http://journals.openedition.org/discours/7260

DOI: $10.4000 /$ discours. 7260

ISSN: 1963-1723

Publisher:

Laboratoire LATTICE, Presses universitaires de Caen

Electronic reference

Ninke Stukker and Ted Sanders, « Another('s) perspective on subjectivity in causal connectives: a

usage-based analysis of volitional causal relations », Discours [Online], 4 | 2009, Online since 11

October 2017, connection on 01 May 2019. URL : http://journals.openedition.org/discours/7260

DOI : 10.4000/discours.7260

\section{(c) $(7)$}

Discours est mis à disposition selon les termes de la licence Creative Commons Attribution - Pas d'Utilisation Commerciale - Pas de Modification 4.0 International. 


\title{
Another('s) perspective on subjectivity in causal connectives: a usage-based analysis of volitional causal relations
}

\author{
Ninke Stukker and Ted Sanders \\ Utrecht institute of Linguistics OTS, Universiteit Utrecht
}

\begin{abstract}
:
Under a linguistic categorization hypothesis causal connectives are taken as categorization devices. Indeed, corpus studies suggest that connectives strongly specialize in one specific causality category, but also that their use is not restricted to the causality categories they are prototypically associated with. If we assume that the meaning of causal connectives can adequately be described with reference to welldefined conceptual categories - how can we explain that variation in the actual usage of connectives occurs? We focus on volitional causal coherence relations, which count as the prototypical usage context of the Dutch causal connective daarom "that's why". Volitional causal relations can alternatively be marked with the connective dus "so" which is prototypically used in epistemic causal relations. Our hypothesis is that volitional causal relations marked with daarom vs. dus systematically differ in terms of subjectivity. We discuss a model of analysis that contains multiple operationalizations of subjectivity and distinguishes between different levels of complexity (sub-clause, clause, and discourse). We find that volitional causal relations with $d u s$ contain subjective elements more often than volitional causal relations with daarom. We interpret this patterning within a usage-based theoretical framework, and propose to analyze cases of volitional $d u s$ as non-prototypical instantiations of $d u s$ 's inherent subjective, prototypically epistemic meaning.
\end{abstract}

Keywords:

causal connectives, volitional causality, epistemic causality, subjectivity, perspectivization, corpus studies, usage-based theory of language, prototypicality structure

\section{Résumé :}

Dans une hypothèse de catégorisation linguistique, les connecteurs de cause sont pris comme des outils de catégorisation. En effet, des études sur corpus suggèrent que les connecteurs sont fortement spécialisés dans une seule catégorie de causalité spécifique, mais aussi que leur usage n'est pas limité aux catégories de causalité auxquelles ils sont prototypiquement associés. Si nous supposons que le sens des connecteurs causaux peut être adéquatement décrit en référence à des catégories conceptuelles bien définies, comment pouvons-nous expliquer qu'il y ait une variation dans leur usage réel? Nous mettons l'accent sur les relations de cohérence causale volitionnelle, qui constituent le contexte d'usage prototypique du connecteur néerlandais daarom 'c'est pourquoi'. Un autre moyen d'expression des relations causales volitionnelles est le recours au connecteur dus 'alors/donc' qui est prototypiquement utilisé dans les relations de causalité épistémique. Notre hypothèse est que les relations de causalité volitionnelle exprimées par daarom vs dus diffèrent systématiquement en termes de subjectivité. Nous proposons un modèle d'analyse qui contient de multiples opérationnalisation de la notion de subjectivité et une distinction entre différents niveaux de complexité (sous-clause, clause, et discours). Nous constatons que les relations causales volitionnelles en $d u s$ contiennent plus souvent des éléments subjectifs que les relations causales volitionnelles en daarom. Nous interprétons cette distribution au sein d'un cadre théorique fondé sur l'usage (usagebased framework), et nous proposons d'analyser les cas volitionnels de dus comme 
des instanciations non-prototypiques du sens de $d u s$, qui est donc intrinsèquement subjectif et prototypiquement épistémique.

Mots-clés:

connecteurs causaux, causalité volitionnelle, causalité épistémique, subjectivité, mise en perspective, étude sur corpus, théorie du langage fondée sur l'usage, structure de prototypicalité

\section{TEXTE INTEGRAL/ FULL TEXT}

\section{Introduction}

1 Causality is fundamental to human cognition. Languages provide their speakers with expressions specifically designed for communicating causal relations. In this paper, we focus on causal connectives - causal expressions functioning at the discourse level of the linguistic structure, relating discourse segment into a coherent whole (cf. Hobbs, 1979; Mann, Thompson, 1988; Sanders, Spooren, Noordman, 1993). Cross-linguistically, languages tend to have more than one connective to express causal relations. In this paper, we focus on the three frequently used Dutch causal connectives with a 'forward' order of presentation (cause precedes the effect):

[1] De temperatuur was al weken onder 0. Daardoor was de vijver bevroren. 'The temperatures were below 0 for weeks. "Daardoor" the pond was frozen.1'

[2] Het was een warme dag. Daarom ging Jan zwemmen.

'It was a hot day. "Daarom" Jan went swimming'.

[3] Hun auto staat er niet. Dus ze zijn niet thuis.

'Their car is not there. "Dus" they are not at home.'

[4] We hebben een feestje. Dus wat wil je drinken?

'We are having a party. "Dus" what do you want to drink?'

2 A common assumption is that different causal connectives communicate different meanings - such as content, epistemic and speech act domains of use, semantic vs. pragmatic levels of representation, or subjectivity; highly comparable notions proposed in the literature so far which would show resemblance to different types of causal coherence relations (cf. on English e.g. Sweetser, 1990; Martin, 1992; Knott, Dale, 1994; Asher, Lascarides, 1998; Knott, Sanders, 1998; on French e.g.: le Groupe L- $\lambda$, 1975; Ducrot, 1983; on German e.g. Pasch, 1983; Günthner, 1993; Keller, 1995). Following this line of reasoning, the meaning and the use of Dutch causal connectives have been characterized with reference to the cognitively basic concept of subjectivity (e.g. Pander Maat, Sanders, 2000; 2001; Pander Maat, Degand, 2001; Degand, Pander Maat, 2003; Pit, 2003; Stukker, Sanders, Verhagen, 2008; submitted). These studies suggest that daardoor, daarom and dus specialize in one specific type of subjectivity. Daardoor ("because of this/that") is typically used in objective causal relations of cause and effect. Dus ("so"), on the other hand, marks subjective relations, either epistemic (argument-conclusion) relations [3], or speech act relations, in which a situation in reality counts as a motivation for the speech act expressed in the effectclause [4]. Daarom ("that's why") typically marks relatively objective causal (reasonaction) relations in observable reality [2].

\footnotetext{
${ }^{1}$ We focus on causal coherence relations mainly from a conceptual perspective. Therefore, the English glosses of our Dutch text material does not contain literal translations. Whenever a direct translation of (parts of) the causal relation is relevant for the understanding of our argumentation, the information necessary for a correct interpretation is presented in the text.
} 
3 In this paper, we adopt the cognitive semantic assumption that a more or less direct relation exists between the linguistic expression of causal relations and cognitive models of causality (cf. Talmy, 1988; 2000; Turner, 1987; Lakoff, Johnson, 1980). More specifically, we assume that causal connectives have a categorization function: when selecting one of the options available in a language, the speaker assigns the causal relation expressed to a specific type of causality. Indeed, corpus studies have shown that language users often systematically prefer one lexical item rather than another (even highly similar) one to express a certain type of causal relationship (e.g. Pander Maat, Sanders, 2000; Pander Maat, Degand, 2001; Degand, Pander Maat, 2003; Pit, 2003; Frohning, 2007; Zufferey, 2007; Stukker et al., 2008). In a minority of cases, however, the relation of connectives to their typical causality category appears to be less straightforward. Various corpus studies have shown that under specific circumstances, connectives are used in contexts which are taken to belong to other connectives' typical contexts of use (e.g. Pander Maat, Sanders, 1995; 2000; Pander Maat, Degand, 2001; Pit, 2003; Stukker et al., 2008; submitted).

4 In this paper we focus on volitional causal relations, reason-action relations, which count as a relatively objective causality type (cf. Pander Maat, Sanders, 2000; Pander Maat, Degand, 2001; Degand, Pander Maat, 2003; Stukker et al., 2008; submitted). In Dutch, volitional causal relations count as the default causality type marked with daarom. Volitional causality can alternatively be marked with $d u s$, which is prototypically used in subjective epistemic causal (argument-conclusion) relations. Consider the contrast between [2] above, and [5]:

[5] Het was een prachtige zonnige dag. Dus ik ging zwemmen.

'It was a lovely, sunny day. "Dus" I went swimming'.

5 How can this pattern be explained? Should it be interpreted as evidence against a categorization approach, as has been proposed in a number of studies (e.g. Pander Maat, Sanders, 2000; 2001; Pander Maat, Degand, 2001; Degand, Pander Maat, 2003; Pit, 2003)? In Stukker et al. (2008; submitted) we reinterpret this finding within a usage-based framework. We propose to analyze 'deviant' contexts of use as non-prototypical members of the same semantic category that is more directly reflected in the connective's prototypical contexts of use. We analyze non-prototypical usage (NPU) events as purposeful rhetorical construals, 'blending' the actual causality type expressed in the causal coherence relation with the causality type prototypically associated with the connective used as a marker (Sanders, Sanders, Sweetser, submitted). Thus, in the inherently volitional causal context of [5] dus seems to mark an aspect of epistemicity, which constitutes dus' PU (see section 3), and which is present in the context of [5], but which is absent in [2]. Our hypothesis is that this aspect characterizes a systematic difference between volitional causal relations marked with dus vs. daarom. The argument is worked out in more detail in section 3.

Previous studies report findings that can be interpreted as evidence in favour of our usagebased categorization hypothesis concerning the contrast between volitional causal relations marked with daarom vs. dus. A problem, however, is that the methods of analysis used in these studies cannot describe the array of subtle variations in subjectivity patterns we encounter in corpora of natural language use. In this paper we discuss an analytic model providing such a description. Our model contributes to the analysis of subjectivity and perspective in NPU volitional $d u s$ vs. PU volitional daarom, because it contains the following elements. First, multiple operationalizations of the notions 'perspective' and 'subjectivity' in terms of linguistic elements help detect a larger variety of patterns of use. Second, we explicitly distinguish between different levels of analysis: construal of subjectivity and perspective within segments, at the level of the segments as a whole, and at the level of the causal relation. Previous studies combined elements from different levels, but failed to explain how the levels interact in the construal of subjectivity and perspective in volitional causal relations. Finally, we introduce the concept of perspective carrier, which enables us to systematically describe the perspective from which the causal relation is 
construed. The model builds on empirical results from previous connective studies, and combines these with cognitive semantic theories concerning perspective and subjectivity.

7 The paper is structured as follows: In section 2 we discuss analyses of the meaning and the use of daardoor, daarom and dus in terms of subjectivity and causality, which were proposed in previous studies. We describe the analytical problems remaining in these analyses. Section 3 presents a model of analysis that aims to solve these problems. In section 4, we demonstrate the procedure of analysis with reference to 'real life' instances of use of daarom vs. dus in volitional causal relations, taken from a corpus of written language. The results of this pilot analysis and remaining questions are discussed in section 5 .

\section{Subjectivity and perspective in daardoor, daarom and dus: Analytical problems}

8 Several studies of causal connectives have proposed that, cross-linguistically, the similarities and differences between connectives can be characterized in terms of 'subjectivity' (e.g. Pander Maat, Degand, 2001; Degand, Pander Maat, 2003; Pit, 2003)2. The importance of this concept in determining linguistic phenomena is widely attested (see for example Traugott, 1989; 1995, Langacker, 1990; Lyons, 1995). Notwithstanding terminological differences (Pit, 2003; De Smet, Verstraete, 2006), theorists agree that subjectivity it is to a great extent equivalent to speaker involvement: A linguistic element is 'subjective' if reference to the speaker is needed for its interpretation. Fragments [6]-[8] below are prototypical usage contexts (PU) of daardoor, daarom and dus in written communication 3

[6] De Boeing 747, het duurste vliegtuig dat rondvliegt, daalt steeds sneller in waarde. De afgelopen jaren is het vermogen van vliegmaatschappijen daardoor met vele miljarden dollars verminderd.

'The Boeing 747, the most expensive plane in the air, is continuing to diminish in value rapidly. During the past years, airlines' capital has "daardoor" decreased by many billions of dollars.'

[7] (In Denmark and in the Netherlands, carcasses of beef cattle older than 30 months are tested for the cattleplague BSE). Andere landen zijn nog niet klaar om elk voor de slacht aangeboden rund te onderzoeken. Zij vernietigen daarom op grote schaal dieren. 'Other countries are not yet ready for testing all bovine animals destined for consumption individually. They destroy "daarom” animals on a broad scale'.

[8] (Dutch soldiers who served in Bosnia relate the high incidence of leukemia among them to frequent exposure to impoverished uranium.) Maar de huidige hypothese wijt de leukemieën aan een virus (...). Het is dus denkbaar dat de soldaten die nu leukemie hebben gekregen, slachtoffer zijn van iets anders dan verarmd uranium.

'But the current hypothesis attributes the leukemias to a virus (...). 'It is "dus" conceivable that the soldiers who suffer from leukemia now, are victims of something else than impoverished uranium.'

9 The differences between the causal relations represented in fragments [6]-[8] with respect to degree of subjectivity can be described as follows: Dus is typically used for marking

\footnotetext{
${ }^{2}$ In addition, a large number of studies on causal connectives in various languages exists in which meaning contrasts are characterized making use of notions that are closely related to 'subjectivity', to mention only a few: propositional vs. illocutionary (le Groupe L- $\lambda$, Pasch, 1983); semantic vs. pragmatic (Knott \& Dale, 1994; Knott \& Sanders, 1998); external vs. internal (Martin, 1992) domains of use (Sweetser, 1990; or closely related notions: Günthner, 1993; Keller, 1995). See for an elaborate discussion of the relatedness of several distinctions used to characterize causal connectives Sanders, 1997; see for a discussion of the relation between domains of use and subjectivity Pander Maat, Sanders, 2000.

${ }^{3}$ Another causality type that is frequently expressed with dus is speech act causality (Sweetser, 1990; cf. introduction). Since the category of speech act causality hardly occurs in written communication (e.g. Pander Maat, Sanders, 1995) we do not take this category into account in the remainder of this paper.
} 
epistemic causal relations, in which a causal relation is constructed on the illocutionary level, between a conclusion of the author presented as the causal effect (het is denkbaar dat 'it is conceivable that...' in [8]), and an argument functioning as the causal antecedent (the fact that the current hypothesis attributes leukemia to a virus). In epistemic causal relations, the speaker functions as the source of the causal relation (it is he who relates argument and conclusion). In other words: reference to the speaker is obligatory in order to interpret the causal relation correctly; hence the causal relation is subjective.

10 This type of speaker involvement is lacking in causal relations typically marked with daardoor and daarom. Fragments [6] and [7] both describe causal relations between states of affairs in the observable world, having their source outside the speaker. Yet, they differ with respect to other causality categories: the causal relation in [7] describes an intentional action vernietigen 'destroy' which is motivated by the situation described in the first segment. Intentionality is absent in fragment [6] where one physical process (daalt steeds sneller in waarde 'is continuing to diminish in value rapidly') induces another one (het vermogen is verminderd met vele miljarden 'capital has decreased by many billions of dollars'), without intervention of a human being. Daarom prototypically expresses volitional causality; daardoor prototypically expresses non-volitional causality. We take both volitional and non-volitional causality to be inherently objective4, but as we will see in section 3, the presence of an intentional, animate being as the 'source' of a volitional causal relation offers an opportunity for introducing subjective elements in the interpretation of the causal relation. Just like the distinction objective-subjective, this distinction according to the presence and absence of intentionality is considered to be a cognitively important one (e.g. D'Andrade, 1987; Verhagen, Kemmer, 1997), and is prominently reflected in the linguistic system as well (e.g. in the concept of agentivity, cf. Delancey, 1984; Lakoff, 1987; Talmy, 1988; 2000; Lyons, 1995).

11 Corpus studies show that the Dutch causal connectives daardoor, daarom and dus conform to this pattern in a majority of cases (Pander Maat, Sanders, 1995; 2000, Degand, Pander Maat, 2003; Stukker, 2005; similar patterns were observed with the 'backward' causal connectives doordat, omdat and want, see Pit, 2003; Pander Maat, Degand, 2001). Figure 1 summarizes relative frequencies confirming this hypothesis in a newspaper corpus $(Z=4.29$; $\mathrm{p}<.001$; Stukker, 2005)5.

\footnotetext{
${ }^{4}$ Opinions differ on the degree of subjectivity of volitional causal relations. Pander Maat, Degand (2001: 218-221) for example propose that volitional causality is inherently subjective, under the assumption that what is causally effective in a volitional causal relation is not the state of affairs presented as the real world cause, but its representation by the protagonist. Therefore, the relation's cause, as well as the relation as a whole, falls within the mental domain of the actor. Hence, volitional causal relations are considered to be inherently subjective. For a similar analysis, see Pander Maat, Sanders, 2000. We will discuss this issue in section 5.

${ }^{5}$ Z-scores reported in sections 2 and 3 were obtained through contrast analysis (Van den Bergh, 1989), reported in Stukker, 2005.
} 
Figure 1. Distribution of daardoor, daarom and dus over categories of causal relations: epistemic, content volitional or content non-volitional ( $N=100$; Stukker, 2005).

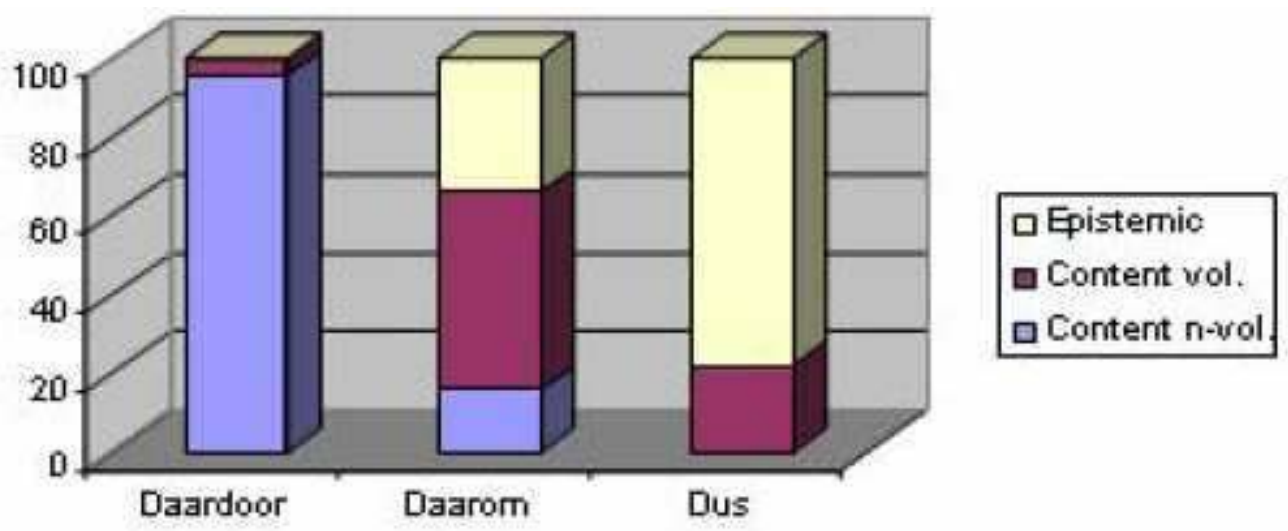

12 However, as becomes evident from Figure 1, each connective can be used in the context of the other causality categories as well. The crucial question we are addressing in this paper is: under the assumption that the meaning of causal connectives can adequately be described with reference to clearly delineated, well-defined conceptual categories - how can we explain that variation in the actual usage of connectives occurs at all? Stukker et al. (submitted) propose to analyze the less frequent, less prototypical acts of categorization as cases of 'subjective construal' of the causality category. This means that the same causal relation in reality may be categorized differently by different speakers, according to their particular understanding of the situation or their rhetorical purposes. This proposal is in line with the suggestion put forward in several studies of linguistic categorization that an expression's meaning is not just an objective characterization of the situation described. Equally important for linguistic semantics is how the speaker chooses to "construe" the situation and portray it for expressive purposes (Langacker, 2002: 315; 1987; Verhagen, 2007, and references cited there). Subjective construals of categorization in terms of causality were found with causal verbs, marking causal relations at the clause level (Verhagen, 2000; see also Verhagen, 1997; Verhagen, Kemmer, 1997).

13 In this paper, we focus on one such 'non-prototypical' context (NPU): The usage of $d u s$ in volitional causal relations; a relation type which is prototypically marked with daarom. Some corpus examples6 are:

[9] (Bystanders rush to help out at the Volendam pub fire.) "Ik woon vlakbij, dus ik ben brandwondencrème gaan halen.

'I live nearby "dus" I ran to get burn ointment.'

[10] (Publishing history of a famous poet). Ze had al eens een paar gedichten naar Maatstaf gestuurd, en [daarover was hij laaiend enthousiast geweest - vond haar poëzie meteen af. $]_{\mathrm{C}} 7$ Dus [hij schreef haar meteen of ze nog meer had $]_{\mathrm{E}}$ en dat werd toen die bundel.

'She had sent some poems to Maatstaf, and [he had loved them - found her poetry had an immediate perfection. $]_{C}$ "Dus" [he wrote her if she had any more $]_{\mathrm{E}}$, and this became her first collections of poems.'

14 Patterns of subjective construal do not seem to occur randomly. A general pattern is that NPU of connectives tend to exhibit elements of their PU in the foreign context (Stukker, et al., 2008; Stukker et al., submitted; see also Pit, 2003 for similar observations regarding

\footnotetext{
${ }^{6}$ Unless stated otherwise, the fragments discussed in this paper are taken from the Dutch daily newspaper Trouw (2001), in the Lexis Nexis Academic newspaper corpus.

${ }^{7}$ If a corpus example consists of more than two utterances, we indicate with the symbols ' $\mathrm{C}$ ' (cause) and ' $\mathrm{E}$ ' (effect) the segments between which the causal relation holds.
} 
backward causal connectives). With respect to volitional causal relations, previous studies suggested that volitional dus-marked contexts are more subjective than those marked with daarom. Dus-marked cases contain an actor who is referentially close to the speaker more often than daarom-marked cases (Pander Maat, Sanders, 2000: 73-4; Pander Maat, Degand, 2001: 239-40). An example is [9] containing a first person actor. In addition, volitional causal relations marked with dus more often contain continuous character perspective than those marked with daarom (Pander Maat, Sanders, 2000: 73-4). Fragment [10] (taken from Pander Maat, Sanders, 2000: 71), where the character hij "he" is the one who is evaluating (in the cause segment) and then acting (in the effect segment), is an example of this continuous character pattern.

15 What aspects of volitional causal relations allow for construal of the causal relation alternatingly with daarom or with dus? The general theoretical idea here is that volitional causality has characteristics in common with epistemic causality - which functions as $d u s^{\prime}$ PU. This commonality is that both causality types originate from some mind; in both types, a 'subject of consciousness' (SOC) plays a crucial role. In epistemic causal relations this SOC acts as a 'concluder'; in volitional causal relations, the SOC is an 'actor' (Pander Maat, Sanders, 2000: 64). Despite this commonality, however, our hypothesis is that subjectivity is not an intrinsic characteristic of volitional causality (see for a more elaborate argument Stukker et al., submitted), but the fact that some SOC necessarily plays a role opens the way to introduce elements of subjectivity in such contexts. The source of subjectivity is then transferred from the speaker to another SOC (Pander Maat, Sanders, 2000; Sanders et al., submitted). This phenomenon is called 'perspectivization' (J. Sanders, 1994; J. Sanders, Spooren, 1997, specifically with reference to causal relations, see Pit, 2003; Sanders et al., submitted). In volitional relations marked with $d u s$, the SOC does not only seem to be relevant as an intentional agent - which is the defining characteristic of volitional causal relations - but also as a subjective agent 'justifying' the particular course of action taken. In other words: by marking the volitional causal relation with $d u s$, the author foregrounds the process of decision making taking place in the relation's SOC. This aspect causes a higher level of subjectivity in the causal relation, and in this respect dus' NPU of volitional causality reflects a defining characteristic of its PU of epistemic causality. (Stukker et al., (submitted). Sanders et al. (submitted) propose to analyze NPU of dus in terms of 'blends' (Fauconnier, Turner, 2002) of the causality categories inherently associated with each one of the connectives. Thus, the use of $d u s$ in volitional causal contexts is taken to evoke a conceptual blending of volitional causality (typically containing a non-author SOC) with epistemic causality (the category typically associated with $d u s$, and typically containing an author SOC), resulting in a subjective construal of an inherently objective causal relation.

\section{Analyzing typical and non-typical usage of causal connectives}

16 The aim of the present paper is to analyze the usage patterns of daarom and dus described in section 2 within a usage-based theoretical framework. Usage-based theories of language assume that variation is an inherent characteristic of language use, and seek to explain patterns of variation with reference to more general cognitive mechanisms (e.g. Langacker, 1987; Bybee, 2006; 2007; contributions to Barlow, Kemmer, 2000). In line with this framework, we propose that an interplay of conceptual and usage factors can explain why the use of Dutch causal connectives does not always conform to abstract definitions that seem to be quite straightforward otherwise. Usage-based theories of language assume that linguistic knowledge is stored and employed as a usage system (e.g. Langacker, 1987; Bybee, 2006; 2007). A semantic category is taken to originate from concrete usage events. It emerges through reinforcement of the commonality inherent in multiple 'usage experiences' (Langacker, 2000: 4). From this perspective, semantic knowledge is defined as 'knowing in what context to use the word properly' (cf. Verhagen, 2000). Thus, in a usage-based approach to language, word meaning is defined in terms of a usage schema, viz. "the 
commonality that emerges from distinct structures when one abstracts away from their points of difference" (Langacker, 2000: 4).

17 Categories that emerge from linguistic experience exhibit prototype effects (e.g. Langacker, 1987; 2000; Geeraerts, Grondelaers, Bakema, 1994; Geeraerts, 1997). 'Prototypicality' refers to the well-known cognitive phenomenon that conceptual categories are not homogeneous; some members of a category are better examples than others. Oranges, apples and bananas are better examples of FRUIT than nuts and olives, which are nevertheless recognized as members of the same conceptual category (Rosch, 1973). The 'best examples' are the category's prototypical members; other members vary to the degree to which they have features in common with the prototype (cf. Wittgenstein, 1953; Rosch, 1973; Rosch, Mervis, 1975). Usage-based theories of language predict that the more frequent, or the more entrenched, contexts of use are the more prototypical members of a category, while the less frequently encountered usage contexts are more 'peripheral' members belonging to the same category, related to the prototype by way of conceptual affinity 8,9 .

18 When we apply these usage-based assumptions to the usage patterns of daarom and $d u s$ in volitional causal relations discussed in section 2, a first noticeable fact concerns the distribution of the connectives over causality categories. Both daarom and dus have a clear statistical preference for one specific category at the expense of other contexts it may be used in. Daarom specializes in volitional causality $(\mathrm{Z}=3.80 ; \mathrm{p}<.001)$, while $d u s$ specializes in epistemic causality $(Z=5.37 ; \mathrm{p}<.001$; see figure 1$)$. We interpret this dissymmetry in distribution as an indication that these contexts of use have a prominent status in the language user's representation of the knowledge regarding the meaning and the use of $d u s$ and daarom; more specifically, that these categories function as the connectives' PU10.

19 Subsequently, our usage based categorization hypothesis predicts that the less frequently occurring usage types of dus and daarom are more peripheral members of the same category - the category's NPU. In the remainder of this paper, we investigate the second consequence of our usage-based categorization hypothesis, namely: the hypothesis that the connectives' NPU exhibit conceptual relatedness to their PU. More concretely with respect to volitional $d u s$ vs. daarom, this hypothesis predicts that volitional dus exhibits conceptual relatedness to dus' PU subjective, epistemic causality. We will investigate the hypothesis that the volitional contexts marked with $d u s$ are construed subjectively more often than the volitional causal contexts marked with daarom, yielding a context that is ambiguous with respect to the degree of subjectivity.

20 We consider the findings from previous studies (discussed in section 2) to be important indications in favour of our general hypothesis, viz.: that NPU volitional dus is used by the writer as an indication that the causal relation has to be construed more 'subjectively' than would have been the case if PU daarom was used as a marker. Yet, we believe that a more detailed analysis of volitional causal coherence relations marked with daarom vs. $d u s$ is needed in order to test this hypothesis adequately. In this section we discuss a model of

\footnotetext{
${ }^{8}$ Empirical evidence in favour of this effect of 'token frequency' is found for example in the phenomena of phonetic reduction of high frequency words and phrases (cf. Bybee, 2006; 2007), the 'conserving effect' the finding that high-frequency sequences become more entrenched in their morphosyntactic structure (e.g. Bybee, 1985), and the 'autonomy effect' - the fact that morphologically complex forms of high frequency can lose their internal structure as they become autonomous from etymologically related forms (Bybee, 1985 - see discussion of these phenomena in Bybee, 2006; see for discussion of other types of frequency effects Hasher, 1984; Geeraerts et al., 1994; Verhagen, 2000; Bybee, 1985; 2007; Goldberg, 2005; Schmid, 2000).

${ }^{9}$ With respect to the usage of causal connectives, this argument is worked out in detail in Stukker et al. (submitted).

${ }^{10}$ An additional argument would be the fact that the causality categories epistemic, volitional and nonvolitional causality correspond to fundamental cognitive concepts, cf. the discussion in section 2 . This argument is worked out in more detail in Stukker et al., submitted.
} 
analysis which aims at describing the linguistic construal of perspective in volitional causal relations in greater detail. We illustrate our model with a pilot analysis of a small sample of natural language use (section 4).

21 Before we are able to compare volitional $d u s$ with volitional daarom at the level of detail we are considering, the model has to solve a number of descriptive problems remaining from previous analyses. We know relatively little about the way perspectivization and subjectivity are linguistically construed in volitional dus vs. volitional daarom. Pander Maat, Sanders (2000) operationalized the notion of perspective mainly in terms of linguistic reference to the actor in the volitional relation. Although they refer to well-known 'space builders' (e.g. Fauconnier, 1985; Sweetser, Fauconnier, 1996; Sanders, Redeker, 1996) such as verbs of cognition; and evaluative, modal or deictic elements, it is not entirely clear to what extent these contribute systematically to the construal of perspective. A more elaborate operationalization of perspective in causal coherence relations is presented in Pit (2003). Different types of perspectivization are categorized in terms of representation modes, which indicate to what extent the actual writer 'lends' his voice to a character in the text. But here, too, the relation between concrete linguistic elements and the categorization of a specific corpus fragment remains largely implicit.

22 As a first contribution to a more detailed analysis of subjectivity and perspective in volitional causal relations, our model operationalizes these concepts making use of various linguistic indicators. In view of our assumption that subjectivity is not necessarily an inherent characteristic of volitional causal relations, but that it has to be construed explicitly, our analysis is based on directly observable linguistic indicators of subjectivity and perspective. The model of analysis is built on empirical results and theoretical conclusions of previous studies. Apart from the studies on subjectivity and perspective in causal connectives discussed so far, these include studies on causal connectives, coherence relations, and linguistic expression of subjectivity and perspectivization from a broader field of study. The model and its theoretical and empirical background are discussed and illustrated in section 4. The model of analysis is summarized in figure 2. The variables' names are listed in the left-hand column; the column in the middle sums up the categories distinguished within variables, ordered in presentation from left to right according to decreasing degree of subjectivity. The model contains variables that establish the degree of subjectivity of the causal relation $(2,5)$ or of its source $(1,3,4,6,7)$.

Figure 2. Linguistic variables used to determine perspective and subjectivity in causal coherence relations.

\begin{tabular}{|c|c|c|}
\hline Variable & Values (subjective . objective) & Level \\
\hline $\begin{array}{l}\text { 1. Enbeddite } \\
\text { 2. SOC teference }\end{array}$ & 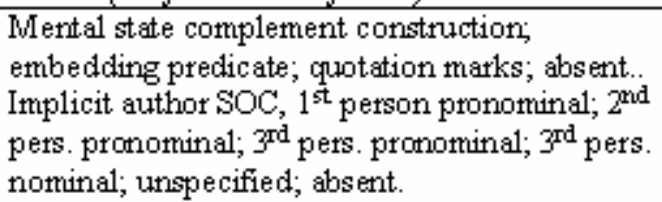 & $\begin{array}{c}\text { Below dlatse } \\
\downarrow\end{array}$ \\
\hline $\begin{array}{l}\text { 3. Subjective } \\
\text { eletrents } \\
\text { 4. Deictic eletuents } \\
\text { 5. Tense }\end{array}$ & $\begin{array}{l}\text { Author (ground); character; urmarked. } \\
\text { Author (ground); character; urumarked. } \\
\text { Future; simple present; present perfect; siruple } \\
\text { past; past perfect. }\end{array}$ & $\downarrow$ \\
\hline $\begin{array}{l}\text { 6. Representation } \\
\text { mode }\end{array}$ & 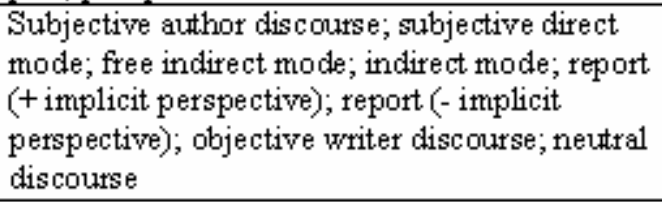 & $\begin{array}{c}\text { Clause } \\
\downarrow\end{array}$ \\
\hline $\begin{array}{l}\text { 7. Ferspective } \\
\text { catrier }\end{array}$ & Author, character, tueutral. & $\begin{array}{c}\text { Relation } \\
\text { betwern clauses }\end{array}$ \\
\hline
\end{tabular}


23 A second new element is that our model tries to make more explicit how perspective characteristics of the causal relation as a whole are derived from lower levels of analysis. First, indicators at the level of the segments are listed, and - if possible - categorized according to their source (speaker, character or 'neutral'). On the basis of these subsegmental characteristics, the degree and type of subjectivity of the segments in isolation is established according to the variable representation mode. Finally, the subjectivity and perspective configuration of the segments in combination is used to establish the source of subjectivity of the causal relation as a whole according to the variable perspective carrier. The right hand column in figure 2 indicates the level of analysis the variable operates on.

24 We took as a starting point for our model of analysis the definition of subjectivity in causal coherence relations presented by Pander Maat, Sanders (2000: 64, 77). This definition explicitly distinguishes between the role of the author of the text and the SOC of the causal relation. The SOC of a causal relation is defined as the person whose intentional actions are seen as the ultimate source of the causal relation. Subjectivity in causal relations is defined in terms of the conceptual distance between the author of the text and this SOC: the smaller the distance, the more subjective the causal relation is (see for similar definitions Pander Maat, Degand, 2001; Pit, 2003). This definition makes explicit the idea that the perspective from which a causal relation is construed need not always be the author's. More specifically, it enables us to analyze causal relations in which subjectivity and perspective are 'carried over' from the author of the text to the causal relation's SOC (cf. section 2).

25 However, analysis of connectives in natural language use suggests that actually a larger variety of 'perspective configurations' seems to occur. A causal relation may be construed from the perspective of the author, the relation's SOC, some other character in the text - or from a combination of these. As an example of the latter case, consider [11], in which the SOC's subjectivity is 'blended' (cf. Sanders et al., submitted) with the author's subjectivity. The writer does not fully engage in the character's reasoning process underlying the action depicted in the causal relation, but rather 'comments' on the process reported with the evaluative expression hoognodig 'highly necessary', and by explicitly projecting a motive (functioning as the P-segment) for the volitional action of the character. Despite these obvious 'author's subjectivity' elements, the causal relation must be categorized as volitional causal and not as epistemic: it does not represent an argument-conclusion relation, but it clearly reports a volitional action. Cases like [11], where writer perspective seems to be 'stacked' onto the character's perspective, cannot be adequately analyzed with the operationalizations of perspective used in previous studies. Fragment [11] will be analyzed in more detail in section 4.

[11] Schreijer vond dat er hoognodig een boerin in de Kamer moest komen, en dus is zij met zelfgemaakte worst en kaas op markten gaan staan.

'Schreijer felt it highly necessary to have a peasant woman in the House of Commons, and "so" she went to the market to sell homemade sausage and cheese'.

26 As a final contribution to the analysis of subjectivity and perspective in volitional causal relations, then, our model introduces the concept of perspective carriers. Usually, the subjectivity of the relation is determined in the actual linguistic analyses of segments in isolation. We think it is important to pay specific attention to the question of the responsibility for the causal relation as a whole. The concept of perspective carrier11 is the subject of consciousness from whose perspective the causal relation is construed - in other words: the perspective carrier is the source of the causal relation's subjectivity. In volitional causal relations, the perspective carrier can be the SOC of the causal relation, the author (or speaker) of the text, or some other character in the text. Corpus examples of these four possibilities will be discussed below.

\footnotetext{
${ }^{11}$ Concepts with a similar function are used in ongoing analyses (e.g. Spooren, Sanders, Huiskes, Degand, in press, Sanders, Spooren; submitted).
} 
27 The concept of perspective carrier is principally different from the concept of SOC of the causal relation. The relation's SOC is a conceptual role, in volitional causal relations this role is always defined as: an intentionally acting character. The perspective carrier is a linguistic concept, perhaps more adequately defined as a 'subject of communication', who is linguistically construed by the author (or speaker) of the text. Thus, the author may choose to foreground either the subjectivity of the character fulfilling the SOC role in the causal relation, his own subjective view, another character's subjective perspective, or no particular perspective, in which case the causal relation is construed from a 'neutral' perspective, or: objectively. Since the identity of the author of the text and the identity of the relation's SOC are given in each particular volitional causal relation, the aim of our model of analysis may be characterized as: identifying the relation's perspective carrier(s).

28 If a perspective carrier is present, the causal relation is subjective, as in fragments [9] and [10]. In [9] the author, referred to with first person, pronominal $i k$ ' I', functions as the causal relation's SOC and as its perspective carrier. In [10], the SOC does not coincide with the editor, to whom is referred with third person pronominal hij 'he', and who functions as the causal relation's perspective carrier. In cases without perspectivization, there is no perspective carrier; the causal relation is objective. An example is fragment [7], in which the SOC is an actor, referred to with third person pronominal zij 'they'. If more than one potential perspective carrier is present, the perspective from which the causal relation is construed is ambiguous, as in fragment [11]. The way our model of analysis establishes presence and identity of a perspective carrier is demonstrated in section 4 .

29 In sum, our model of analysis establishes the following aspects of a volitional causal relation:

1. Its degree of subjectivity;

2. The source of the subjectivity: the actual author/ speaker or some other SOC;

3. The relative distance between the actual author/ speaker and the SOC.

\section{Corpus analysis: Subjectivity and perspective in volitional causal relations marked with dus vs. daarom}

30 In this section, we report the results of an explorative study in which we apply the model to a small sample of natural language use. The hypothesis explored in the remainder of this paper is: Volitional causal relations marked with $d u s$ are construed from a subjective perspective more often than volitional causal relations marked with daarom. We believe that the methodology of corpus analysis yields rather direct evidence in relation to our hypothesis. In the first place, our hypothesis concerns patterns of usage of dus vs. daarom. These can be directly inferred from corpora. However, ultimately, our usage-based categorization hypothesis also contains a claim concerning the inherent meaning of causal connectives. Because of the assumed usage-based character of semantic knowledge, patterns of language use are taken to provide rather direct evidence not only for usage patterns per se, but for the content and form of the semantic categories as well (cf. the discussion in section 3).

31 We tested our hypothesis against a mixed corpus of newspaper texts in which various national daily newspapers and various genres were randomly included. Only unambiguous cases of volitional causality were included in the analysis. Our sample contained 23 unambiguous volitional causal relations with $d u s$. In this explorative analysis, we compared the dus-marked volitional causal relations in our sample with the first 23 volitional causal relations marked with daarom occurring in our sample12,13. Differences in distribution were analyzed with contrast analysis (Van den Bergh, 1989).

\footnotetext{
12 The sample of newspaper text used here was originally constructed for a study investigating the meaning and the use of daardoor, daarom and dus (reported in Stukker, 2005). 100 occurrences of each connective
} 
32 We find that our hypothesis is corroborated on the level of analysis of the causal relation as a whole: dus occurs with subjective perspective carriers more often than daarom [4.3]. We interpret this finding as evidence in favour of the usage-based categorization hypothesis, of which our present hypothesis concerning the differences between dus and daarom is a specification. At the same time, none of the 'intra-clausal' [4.1] and 'clause' [4.2] variables turned out to be by themselves sufficient to characterize the difference between $d u s$ and daarom. We return to this issue in section 5. Below we discuss how the model of analysis helps elucidate patterns of subjectification in individual volitional causal relations.

\subsection{Subjectivity and perspective within segments}

33 In this section, we discuss lexical and grammatical categories which are used to indicate the degree of subjectivity expressed within each segment of the causal relation; this is the 'below clause level' in our model of analysis. The causal relation may be part of a larger stretch of perspectivized discourse. Therefore, two utterances preceding the causal relation were included in the analysis of the cause segment14. Distribution of dus and daarom over the categories within variables is reported in the Appendix. Since none of the below clauses variables yielded significant differences between volitional dus and daarom, the aim of our discussion is not to contrast volitional dus with daarom, but rather to illustrate how our model of analysis increases our understanding of how subjective perspective in volitional causal relations is construed. We illustrate our model of analysis with reference to fragments [12]-[17]. Some of the fragments were discussed earlier in the text.

34 Fragment [12] contains a typically objective causal relation. Linguistic indicators of subjectivity and perspective are lacking. By contrast, fragments [13]-[17] show various subjectivity patterns representative of the patterns observed in our sample.

[12] (In Denmark and in the Netherlands, carcasses of beef cattle older than 30 months are tested for the cattleplague BSE). Andere landen zijn nog niet klaar om elk voor de slacht aangeboden rund te onderzoeken. Zij vernietigen daarom op grote schaal dieren. Other countries are not yet ready for testing all bovine animals destined for consumption individually. They destroy "daarom" animals on a broad scale.

[13] (Bystanders rush to help out at the Volendam pub fire.) "Ik woon vlakbij, dus ik ben brandwondencrème gaan halen."

"I live nearby "dus" I ran to get burn ointment."

[14] (From a letter to the editor.) Het is allemaal heel goed te begrijpen dat [de realistische adoptieouders, na de wachttijd van vele jaren, hun kindje zo snel mogelijk willen hebben. $]_{\mathrm{C}}$ Dus [kiezen ze voor een kindje uit China of een ander 'snel' land $]_{\mathrm{E}}$. It is all very well understandable that [realistic adoption parents, after having had to wait for years, want their baby child as soon as possible.]C "Dus" [they opt for a child from China or any other 'fast' country. $]_{\mathrm{E}}$

were analyzed. As the frequency of use of the connectives differs (the ratios of use in this sample were established as follows: daardoor : daarom : dus = $1: 1.81: 3.11$; see Stukker et al., submitted) the connectives come from samples that differ in size (in order to obtain 100 instances of $d u s$ we had to analyze a smaller amount of text from the same sample the 100 daarom fragments were taken from). However, since the sample as a whole was constructed in a consistent, completely randomized manner, we do not expect that including in our present analysis more instances of volitional daarom from the same sample would have led to different results.

${ }^{13}$ Note that in doing so, we approach our usage-based categorization hypothesis only from a semasiological point of view (given the connectives, what relation do they express? Cf. Geeraerts, 1997). For a complete understanding of the relation between connectives and the conceptual understanding of causality, we need to take into account the onomasiogical level as well (Given the relations, what connectives can they be expressed with? Cf. Geeraerts, 1997). We return to this issue in section 5.

14 This is an arbitrary choice. In future analysis we plan to investigate larger amounts of context (e.g. paragraph, or complete text) preceding, and following the causal relation. 
[15] "Omdat de techniek van de huidige dansers beter is geworden, [mag en moet je een oud ballet daaraan wel aanpassen.] $]_{C}$ Massine zelf deed dat in 1960 ook. Dus [laat ik de enkele pirouettes van destijds nu dubbel draaien. Benen moeten hoger dan toen opgetild." $]_{\mathrm{E}}$

Because the technique of present day dancers has improved, [one may and must adapt an old ballet to that $]_{\mathrm{C}}$. Massine himself did that too in the 60's. "Dus" [I have the single pirouettes of that time spin twice now. Legs must be raised higher than in the past. $]_{\mathrm{E}}$

[16] Schreijer vond dat er hoognodig een boerin in de Kamer moest komen, en dus is zij met zelfgemaakte worst en kaas op markten gaan staan.

Schreijer felt it highly necessary to have a peasant woman in the House of Commons, and "dus" she went to the market to sell homemade sausage and cheese.

[17] (Interview with 'multi talent' Theo Nijland.) [Zijn broer besloot dat het tijd was om echt door te breken.] "Je liedjes zijn zó prachtig; waarom zitten er dan maar zo weinig mensen in de zaal?" En eigenlijk irriteerde Theo Nijland (46) zich er zelf ook aan dat 'de machine niet goed liep'. Dus [zei broer Wout zijn baan op als pr-man bij de PvdA en ging hij de barricaden op om Theo te promoten. $]_{\mathrm{E}}$

[His brother decided that it was time to break through for real.] "Your songs are so beautiful; why is it that there is only a small audience at concerts? And as a matter of fact, Theo Nijland (46) himself was annoyed too by the fact that 'the engine didn't run well'. "Dus" [brother Wout quit his job as a PR manager with the PvdA (a Dutch political party) and he stood on the barricades with the aim of promoting Theo. $]_{\mathrm{E}}$

\subsubsection{Linguistic embedding of perspective}

35 Perspectivization may (but need not) be explicitly signaled with syntactic or lexical elements embedding a proposition within a specific perspective. The variable linguistic embedding of perspective classifies explicitly 'perspectivized' segments according to embedding type, but it does not specify for perspective type (author or non-author character, or neutral). A well-known embedding strategy is the use of quotation marks; an example is fragment [13]. A stretch of written discourse that is embedded by quotation marks represents a verbal quotation of another author or speaker. The quotation marks may or may not be combined with a parenthetical (she said, he asked, etc.) at the beginning or the end of the embedded stretch of discourse. This embedding strategy is known as the 'direct representation mode', indicating that another author's or speaker's thoughts and formulations are directly represented (cf. J. Sanders, 1994: 44-8, and references cited there; see also section 4.2). Subjectivity in quotations is usually carried over from the author of the text to the embedded character; see default cases like [13].

36 Other types of embedding constructions function as an indication that the author of the text reports a state, process or event from some other person's perspective. In our sample, we found a number of complementation structures in which a matrix clause containing a verb of communication, cognition, or perception does not "express events of seeing, knowing, saying, etc. just as simplex clauses with such verbs mostly do", but rather "invites an addressee to identify with a particular perspective on an object of conceptualization that is itself represented in the embedded clause" (Verhagen, 2005: 79). Fragment [17] contains an example of such a pattern. The expression zijn broer besloot dat... 'his brother decided that...' in the cause segment opens the perspective of 'his brother' whose evaluation that het was tijd om echt door te breken 'it was time to break through for real' is represented. Fragment [16] contains another example of embedding by complementation. Schreijer vond dat... (indirectly translated with 'Schreijer felt...') embeds the proposition er moet hoognodig een boerin in de Kamer komen 'it (is) highly necessary to have a peasant woman in the House of Commons'. A final example is fragment [14] Het is allemaal heel goed te begrijpen dat... 'It is all perfectly understandable that...'. Since this structure embeds the 
complete causal relation within the perspective of the author of the text, it does not affect the character perspective of the causal relation itself.

\subsubsection{Linguistic reference to the causal relation's SOC}

37 Previous studies suggest that various types of linguistic reference to the causal relation's SOC represent various degrees of 'author-SOC distance' and hence signal different degrees of subjectivity (Pander Maat, Sanders, 2000: 73-4; Pander Maat, Degand, 2001: 239-40; cf. discussion in section 2). An intuitively clear example of 'author-SOC nearness' are cases in which the relation's SOC referentially coincides with the author, or in the case of fragment [13]: the quoted speaker "Ik woon vlakbij, dus ik ben brandwondencrème gaan halen." 'I live nearby "dus" I ran to get burn ointment'. In addition, it is assumed that various types of 'non-speaker' SOC reference types indicate varying conceptual distances to the speaker. For example, pronominal expressions are considered to be "close to the speakers, and more likely to indicate a subjectified SOC, than when the SOC is referred to with a nominal expression; while SOC's that are left unspecified or implicit, as may be the case in passive constructions (e.g. Pander Maat, Sanders, 2000: 69; Pit, 2003: 137-8; Evers-Vermeul, Stukker, 2003: 117), are considered to be construed at a large distance from the speaker, and as a consequence, are least likely to be subjectified. Pronominal expressions are used in contexts in which the person referred to is already introduced and conceptually 'accessible' (cf. Ariel, 1990). Perspectivization and identification with a conceptually accessible SOC is more likely than with a, in the specific context, newly introduced person (cf. the notion of 'empathy' in Kuno, 1987: 204-6). It is expected that 'non-speaker SOC' can only be subjectified if additional subjectivity markers are present. This would explain why fragments [13]-[17], in which additional markers are present (see below), are marked with $d u s$, while fragment [12] in which additional markers are absent is marked with daarom.

\subsubsection{Subjective elements}

38 Another type of linguistic expressions construing subjective discourse is subjective elements. Languages contain numerous lexical elements that can only be interpreted in relation to some subject of consciousness. In linguistic studies different types of 'subjectivity markers' (Pit, 2003: 138-41) are discussed under various headings (e.g. Banfield, 1982; Langacker, 1990; Finegan, 1995; J. Sanders, Spooren, 1997). In general terms, subjectivity is expressed when the author displays an attitude towards the predicated information (J. Sanders, Spooren, 1997: 91). In many studies, two main types of subjectivity markers are distinguished: markers of 'evidentiality' and markers of 'affect' (e.g. Biber, Finegan, 1989). The former type concerns the truth of a given proposition, and we expect to find these markers mainly in epistemic causal relations. We expect that markers of affect will be especially relevant in volitional causal relations. These markers may take the form of adverbs (luckily, hopefully), adjectives (good, nice, attractive), verbs or verbal constructions (love, hate, She's fond of), focus or modal particles (even, already, still, only) (Biber, Finegan, 1989; examples reproduced from the discussion in Pit, 2003: 138-141).

39 Pit analyzes subjectivity markers in order to establish the degree of subjectivity of epistemic causal relations. However, we assume that subjective elements occur in any type of causal coherence relation, and that they can be used as indications for subjectification of the coherence relation regardless of its conceptual category. Since we are primarily interested in the distribution of dus and daarom over various sources of subjectivity, we do not only compare the mere occurrence of subjective elements in dus and daarom contexts; we also categorize the source of subjectivity. We distinguish between subjectivity of the author of the text and subjectivity of a character reported by the author. It is generally assumed that author subjectivity is more subjective than character subjectivity (e.g. J. Sanders, 1994; Pander Maat, Sanders, 2000; Pit, 2003).

40 In fragment [15], the modal expressions mag ('may') and moet ('must') construe author subjectivity in the cause segment: je mag en je moet een oud ballet daaraan wel aanpassen 
'you may and you must adapt an old ballet to that'. In the cause segment of fragment [17] subjectivity is construed that belongs to the embedded character broer Wout 'brother Wout', who judges that het was tijd om echt door te breken 'it was time to break through for real'. The cause segment of fragment [14] contains subjective elements from both sources: author's subjectivity and character's subjectivity. In the causal relation itself, the author of the letter reports an evaluation attributed to realistische adoptieouders 'realistic adoptive parents', who willen hun kindje zo snel mogelijk hebben 'want to have their child as soon as possible'. Preceding this subjective element attributed to the character, the fragment contains an evaluation to be attributed to the author of the letter herself: het is allemaal heel goed te begrijpen 'it is all perfectly understandable'. This evaluation is predicated over the complete causal relation, and does not lead to ambiguity in terms of subjectivity: it is clear that the causal relation is construed from the perspective of the 'adoptive parents'.

41 Interestingly, the cause segment of fragment [16] Schreijer vond dat er hoognodig een boerin in de Kamer moest komen 'Schreijer felt it highly necessary to have a peasant woman in the House of Commons' seems to contain subjective elements from two different sources. The second one occurring, the modal verb moest 'must' clearly belongs to the SOC of the causal relation, Schreijer. The first occurring signal is the evaluative element hoognodig 'highly necessary', which could potentially be attached to the causal relation's SOC, but which is more likely to be ascribed to the author of the fragment. A remarkable feature of this element is its ironical tone of voice, which is not congruent with the inherent SOC's perspective. Rather, it seems to be an evaluative comment of the actual speaker. We will see below that this fragment contains more indications that this fragment is ambiguous for perspective carrier type.

\subsubsection{Deictic elements}

42 We focus on 'point of view deictics', indicating the viewpoint from which a proposition is presented (J. Sanders, 1994: 8; cf. Doron, 1990). We analyze deictic expressions that must be interpreted with reference to a specific perspective. The 'deictic center' of an utterance is determined by expressions e.g. of time huidige 'current', oud 'old', destijds 'then', nu 'now' in [15], or place: vlakbij 'nearby' in [13]; and referential expressions, such as broer 'brother' in [17]. Tense and first and second person pronouns are by definition bound to the speaker (J. Sanders, 1994: 42), hence, these cannot be used as indicators for the causal relation's perspective carrier. Since we are primarily interested in the distribution of $d u s$ and daarom over various sources of subjectivity, we do not only compare the mere occurrence of deictic elements in dus and daarom contexts; we also categorize the deictic center. We distinguish between author (or quoted author or speaker) as a deictic center [13, 15], or the embedded character (e.g. 'Theo Nijland' in [17] as a deictic center. Note that in [17], the deictic element broer 'brother', being a relational expression, yields a different source of subjectivity (namely: Theo Nijland himself) than the subjective element (Theo Nijland's brother; cf. discussion above) does.

\subsubsection{Tense}

43 Tense is taken to represent the conceptual distance between the author (or quoted author or speaker) and the proposition expressed (Fleischman, 1990). Hence, it is likely that tense is used to indicate differences with respect to subjectivity. Several authors have pointed out that tense plays an important role in construing causality in discourse (e.g. Lascarides, Asher, 1993; Oversteegen, 2005). Our analysis of tense in terms of subjectivity is largely based on the discussion and results reported by Pit (2003: 146-51), which is determined on the basis of the expressive function of tense, as it is described by Fleischman (1990).

44 A complication in interpreting our data is that Fleischman's (1990) theory, and hence, Pit's (2003) subjectivity cline, are based on French narrative texts. We do not know beforehand to what extent Fleischman's findings can be generalized to Dutch newspaper texts. A first doubt concerns the function of present tense. In narrative text, present tense indicates a high 
degree of involvement of the narrator with the characters in the text. In newspaper texts, on the other hand, the present appears to be the default option used by the author for reporting events. Approximately half of the cases of dus and daarom in our sample are construed with the present tense (e.g. [14]); this finding corroborates patterns reported by Pit (2003: 201-2) concerning the backward Dutch causal connectives doordat, omdat and want.) Second, it is not entirely clear how the Dutch 'simple past' relates to the two simple past tenses in French, the 'passé simple' (implying an objective and distanced view) and the 'imparfait' (evoking an 'experiencer in the past', Banfield, 1982). We find in our sample relatively many cases of simple past tense with dus. We have the impression that in the perspectivized causal relations marked with dus, the simple past construes an 'experiencer in the past', rather than a distanced view of 'what once happened in the past' (cf. discussion in Pit, 2003: 147-9). An example is [17]: Zijn broer besloot dat het tijd was om echt door te breken (...) Dus zei broer Wout zijn baan op (...) 'His brother decided it was time to break through 'for real' (...) "Dus" brother Wout quit his job (...)'. In both segments of this causal relation, simple past tense is used. The effect seems to be that interviewee Theo Nijland 'reexperiences' the process that led to his brother choice to change his career.

45 According to (Fleischman, 1990: 232, 253) present perfect tense "relates the past to the present of the speaker", hence our model of analysis classifies this category as being relatively subjective. Fragments [13] and [16] contain examples of this pattern. In [16], the shift from 'imperfective tense' in the cause segment to 'perfective tense' in the effect segment (Schreijer vond dat er hoognodig een boerin in de Kamer moest komen, en dus is zij met zelfgemaakte worst en kaas op markten gaan staan. 'Schreijer felt it highly necessary to have a peasant woman in the House of Commons, and "dus" she 'has gone' (went15) to the market to sell homemade sausage and cheese') seems to signal a shift from actor perspective to author's perspective (Fleischman 1990). This is in accordance with an ironic element occurring in the effect segment - the speaker's highlighting of the fact that the SOC Schreijer is (...) met zelfgemaakte worst en kaas op de markt gaan staan 'went to the market 'to sell homemade sausage and cheese'- and not to promote her candidature, which she undoubtedly aimed at doing while selling those products, and which is of course a much more effective course of action for attaining the goal presented as cause. In [13], tense is shifted from 'present' to 'present perfect' Ik woon vlakbij, dus ik ben brandwondencrème gaan halen ('I live nearby, "dus" I ran16 to get burn ointment'), which can be explained by Fleischman's characterization that the present perfect tense relates the past (in which the reported event took place) to the present of the speaker's 'here and now'.

\subsection{Subjectivity and perspective at the level of the segments as a whole: representation mode}

46 As a next step in our analysis, we derive from the 'intra-segmental' subjectivity and perspective indicators discussed in 4.1, the subjectivity type of the segments of the causal relations. We use the concept of representation mode to discuss various aspect of subjectivity at the level of the segments. This variable characterizes how speech or thought of the author (or speaker) of a text or a character in the text is represented. Speech, thoughts or events may be construed subjectively or objectively. The subjectivity and perspective indicators discussed in the previous section add up to the representation mode of each segment in the causal relation. In our discussion of representation mode, we largely follow J. Sanders (1994), and Pit's (2003) adaptation of this concept to causal coherence relations.

47 It is at this point in our discussion of corpus examples that the advantages of the multiple operationalization of subjectivity and perspective and the incremental nature of our model of analysis become evident. First, by separating the analysis of subjectivity and perspective

\footnotetext{
${ }^{15}$ The tense configuration used in the Dutch version of the causal relation cannot be directly translated into English.

${ }^{16}$ See previous footnote.
} 
according to level of complexity, the basis for the analytic choices and interpretation is made maximally explicit. Below we illustrate how the most important representation modes in our sample are derived from the subjectivity signals within the clause, discussed in 4.1.

48 The maximally subjective representation mode in our model is subjective author discourse. A segment is construed from author perspective if his speech or thought is directly represented. Elements of author's subjectivity may be represented in the form of subjective elements, e.g. evaluations, cf. [16]: hoognodig 'highly necessary' (Schreijer vond dat er hoognodig een boerin in de Kamer moest komen 'Schreijer felt it highly necessary to have a peasant woman in the House of Commons), and in [14] Het is allemaal heel goed te begrijpen... 'It is all perfectly understandable that...'), which are classified as subjective author's discourse.

49 The category second in subjectivity rank is direct mode, concerning speech or thought of someone different from the author of the text, which is signaled by the author with quotation marks. Examples are [13] Ik woon vlakbij, dus ik ben brandwondencrème gaan halen 'I live nearby "dus" I ran to get burn ointment', and [15] Omdat de techniek van de huidige dansers beter is geworden, mag en moet je een oud ballet daaraan wel aanpassen. (...). Dus laat ik de enkele pirouettes van destijds nu dubbel draaien. "Because the technique of present day dancers has improved, one may and must adapt an old ballet to that. (...). "Dus" I have the single pirouettes of that time spin twice now'. Our model diverges from Sanders' (1994) and Pit's (2003) classification in that we distinguish between subjective direct mode ([15]: evaluative expressions mag 'may' and moet 'must' - see discussion of subjective elements in 4.1 and objective direct mode [13]. The latter category is classified on a par with objective author's discourse in the category 'neutral discourse' (see below).

50 As has become clear by now, texts may also represent subjectivity belonging to subjects of consciousness other than the author of the text (including quotations). Our model distinguishes between various types. The first type concerns the representation of a character's speech or thought in a more or less authentic way: indirect mode and free indirect mode. These categories differ somewhat in terms of subjectivity, but as neither of the categories occur frequently in our sample (see the Appendix), we discuss only indirect mode as an example. A common way to construe non-speaker perspective is by a complementation construction (verbs of speech, cognition, or perception) which serves as an embedding construction for the character's subjective thoughts (Sanders, 1994: 53; see the discussion of the variable 'linguistic embedding of perspective' in section 4.1). As an example consider the cause segment of [17] Zijn broer besloot dat het tijd was om echt door te breken. 'His brother decided that it was time to break through 'for real'. In this construction, the subjective evaluation is explicitly attributed to the character in the text referred to as zijn broer 'his brother'.

51 The second type of 'other's perspective' is of particular relevance for our analysis of volitional causal relations. It concerns the representation of characters whose 'state of consciousness' is reported from outside (J. Sanders, 1994: 55). This representation mode of character speech or thought counts as less direct than (free) indirect speech discussed above. Since volitional causal relations by definition concern reports of actions (the only actions that can be performed in discourse are speech acts, which concerns a different type of causality), the only way the effect-segment of the volitional causal relation can be subjectified is by reporting the SOC's state of consciousness. In our model of analysis we distinguish between a category 'report including implicit perspective' and a category 'report without implicit perspective' 17. Linguistic elements signaling implicit perspective are private state reports such as reports of perception and cognition. Implicit perspective of the SOC is created in the effect segment of fragment [17]- Dus zei broer Wout zijn baan op als

\footnotetext{
${ }^{17}$ Following J. Sanders (1994) and Pit (2003). We do not, however, follow Pit in making a subdistinction within the categories of 'reporting' according to the identity of the reporter.
} 
pr-man bij de PvdA en ging hij de barricaden op om Theo te promoten "'Dus" brother Wout quit his job as a PR manager with the PvdA and stood on the barricades with the aim of promoting Theo' - by mentioning the goal for the action: om Theo te promoten 'with the aim of promoting Theo'. The reader thus co-experiences the SOC's process of decision making. An example of reporting without implicit perspective is fragment [12] above. As was argued earlier, this fragment does not contain any indication of subjectivity, hence it is classified as 'neutral perspective'.

52 Apart from making analytical choices and interpretations maximally explicit, a second advantage of our model of analysis is that it allows us to describe and understand various types of ambiguities. At the present point in the analysis, the ambiguous perspectives that arose during our analysis of within-segment subjectivity indicators (see 4.1) can now be diagnosed as follows. Consider [18], discussed as [16] above:

[18] Schreijer vond dat er hoognodig een boerin in de Kamer moest komen, en dus is zij met zelfgemaakte worst en kaas op markten gaan staan.

'Schreijer felt it highly necessary to have a peasant woman in the House of Commons, and "dus" she went to the market to sell homemade sausage and cheese'.

53 In this fragment, different types of perspective are blended. The relation's SOC is $z i j$ 'she', and the fragment contains embedding with cognition verb vond 'felt' as an explicit signal that the relation is presented from 'her' perspective. So far, the relation in [18] resembles the ones in fragments [13], [14], and [15]. However, unlike these fragments, [18] contains explicit signals that the speaker's perspective is relevant to the interpretation of the relation as well. Indicators of speaker perspective are the subjective element hoognodig 'highly necessary', the irony brought about by the effect segment, which seems to be rather an ironic projection on the speaker than the genuine motive the SOC might have had for performing the action reported, and the shift from 'imperfect tense' to 'perfect tense' (which cannot be translated into English, see discussion of this example in section 4.1). Fragment [18], then, is ambiguous for representation mode. The character SOC's subjectivity is blended with the author's subjectivity. Thus, our model of analysis is able to capture the ironical effect of the specific wording of [18]: the process of decision making depicted in this fragment did not actually take place in the relation's inherent SOC, but is attributed to her by the speaker, yielding two segments that are ambiguous between subjective author discourse and indirect mode (cause segment) and perspectivized report (effect segment) of the causal relation's SOC.

54 A different type of ambiguity is manifested in fragment [19], which was discussed as [17] above.

[19] (Interview with 'multi talent' Theo Nijland.) [Zijn broer besloot dat het tijd was om echt door te breken.] "Je liedjes zijn zó prachtig; waarom zitten er dan maar zo weinig mensen in de zaal?" En eigenlijk irriteerde Theo Nijland (46) zich er zelf ook aan dat 'de machine niet goed liep'. Dus [zei broer Wout zijn baan op als pr-man bij de PvdA en ging hij de barricaden op om Theo te promoten. $]_{\mathrm{E}}$

[His brother decided that it was time to break through 'for real'. $]_{\mathrm{C}}$ "Your songs are so beautiful; why is it that there is only a small audience at concerts? And as a matter of fact, Theo Nijland (46) himself was annoyed too by the fact that 'the engine didn't run well'. "Dus" [brother Wout quit his job as a PR manager with the PvdA (a Dutch political party) and he stood on the barricades with the aim of promoting Theo. $]_{\mathrm{E}}$

55 In the cause segment, the causal relation's SOC broer Wout 'brother Wout' is construed subjectively by the complement construction besloot dat 'decided that...' and with the subjective evaluation het was tijd om echt door te breken 'it was time break through for real' in the cause segment (cf. section 4.1). The SOC's perspective is reflected even more directly in the utterance following the cause segment, construed in direct mode, which serves as a specification of the evaluation presented in the cause segment. The SOC's implicit 
perspective is continued in the effect segment with the mentioning of the goal of his action 'with the aim of promoting Theo'. However, the deictic expression broer 'brother', which is used to refer to the SOC twice, indicates that Theo Nijland himself is to be construed as a second source of subjectivity. Nijland's perspective is construed in the second utterance following the cause segment, by way of a complementation construction Theo Nijland (46) irriteerde zich er zelf ook aan (sic) dat...(indirectly translated with 'Theo Nijland (46) himself was annoyed too by the fact...') and the evaluation de machinerie liep niet goed (indirectly translated 'the engine didn't run well'). Thus, both cause and effect segment in this fragment seem to combine (free) indirect mode from two different sources: Theo Nijland, from whose perspective the interview as a whole is construed, and the perspective belonging to Nijland's brother, who functions as the causal relation's SOC.

\subsection{Subjectivity and perspective on the level of the causal relation: perspective carrier}

56 So far, we discussed how linguistic indicators of subjectivity and perspective create subjectivity at the clause level (sections 4.1 and 4.2). In other words, we analyzed the degree of subjectivity at the level of the causal relation's segments. The ultimate goal of our analysis is, however, to establish the perspective from which the volitional causal relation as a whole is construed. In order to distinguish relational perspective from the notions 'author of the text' (or quoted speaker) and the causal relation's SOC, we introduced the concept of perspective carrier. This concept denotes the perspective from which the causal coherence relation is linguistically construed (cf. section 3). Our analysis so far suggests that various sources can function as the relation's perspective carrier: the relation's SOC, another SOC functioning as a character in the text, or the author of the text. Alternatively, volitional causal relations may be construed from neutral perspective, or objectively.

57 How is relational perspective to be derived from perspective configurations at the level of the segments in isolation? This issue has largely remained implicit in previous studies of subjectivity and perspectivization in volitional causal relations18. Studies either put forward claims concerning (combinations of) perspective at the level of the segments (e.g. Pit, 2003), or assume that volitional causal relations are subjective by default (cf. section 2). We will not solve this issue here, but the analysis presented below is a first attempt to argue how subjectivity and perspective of the causal relation as a whole may be derived from the lower levels of analysis. Since various studies found that volitional causal daarom and dus indeed differ with respect to 'relational continuity of the perspective' (see the discussion in section 2), the explicit construal of continuous perspective seems to be an obvious starting point of our analysis of relational perspective. However, if we diagnose 'perspective continuity' on the basis of explicit linguistic signals alone - as our model of analysis does- we find that this concept is not very instructive with respect to the differences between volitional causal dus vs. daarom. Table 1 summarizes our findings.

${ }^{18}$ Cf. Pander Maat, Sanders, 2000 who discuss the relational concept of 'continuous' vs. 'discontinuous perspective', but do not specify how perspective continuity is systematically derived from characteristics of the causal relation's segments or larger context. 
Table 1 Overview of perspective configurations with dus and daarom in our sample.

\begin{tabular}{llll}
\hline & Daarom & Dus & Total \\
\hline Author-author & 0 & 1 & 1 \\
Author-neutral & 3 & 3 & 6 \\
Neutral- Author & 0 & 0 & 0 \\
Author- Charact. & 1 & 5 & 6 \\
Charact.- Author & 0 & 0 & 0 \\
Charact.- Charact. & 2 & 2 & 4 \\
Charact.- Neutral & 9 & 4 & 13 \\
Neutral- Charact. & 2 & 3 & 5 \\
Neutral- Neutral & 3 & 1 & 4 \\
Amb. & 3 & 4 & 7 \\
\hline Total & 23 & 23 & 46 \\
\hline
\end{tabular}

58 If we simply 'add up' presence and absence of subjectivity indicators, and source of subjectivity per segment, we must assume that only the cells 'Author-author' (daarom: 0; dus: 1) and 'Character-character' (cases in which both segments refer to the same person: daarom: 2; dus: 2) and 'author-character' (only cases in which both segments refer to the same person19: daarom: 1; dus: 5) contain continuous perspective. Examples of continuous character perspective are [13] and [14]. An example of continuous actor perspective in which the cause segments has author perspective is [15]. An example of an explicitly construed author perspective carrier is [20]:

[20] (Discjockey Ferry Maat leaves the broadcasting company) Hier was een gekrenkte ziel aan het woord. [Vooral dat voorgelezen citaatje uit een brief van de NCRV-leiding ('Er zijn passende maatregelen genomen om u de toegang tot het pand te ontzeggen') doet vermoeden dat er onrecht in het spel is: wie wil er niet graag bij de NCRV naar binnen?] $]_{\mathrm{C}}$ Dus [even bellen maar.] $]_{\mathrm{E}}$ Mijnheer Maat, hoe is het met $\mathrm{u}$ ?

'This is a hurt soul speaking. [Especially the quote from the letter from the NCRV directors read aloud ('Adequate measures have been taken in order to deny you access to the building') suggests that wrong has been done: who doesn't want to enter the NCRV? $]_{\mathrm{C}}$ "Dus"[let's just give him a ring. $]_{\mathrm{E}}$ Mr. Maat, how are you doing?'

59 In [20] author subjectivity is construed in the cause segment by the complement construction ... doet vermoeden dat ... 'suggests that ...'. Author subjectivity in the effectsegment is conveyed by the particles even and maar, the meaning of which is approximated by English 'Let's just give him a ring' - a positive evaluation of the act of making a phone call20.

60 We interpret this finding as a suggestion that using only explicit linguistic marking is too strict a basis for characterizing perspectivization and subjectivity at the level of the causal relation (we return to this issue in section 5). Previous studies suggested that a default

${ }^{19}$ Our model of analysis does not take into account the referential value of the 'embedded character'. Following Pander Maat, Sanders (2000: 69; see also Langacker, 1990) we assume that, on the one hand, $1^{\text {st }}$ person reference is more likely to be subjectified than $3^{\text {rd }}$ person reference (see 4.1), but on the other hand, that reference to an SOC who is not the speaker as well as explicit speaker references express a certain distance between the author of the text and the person referred to in the text.

${ }^{20}$ Note that this is a very rare case of 'performative' volitional causality (an adhortative construction). The effect segment does not seem to only communicate the actual act of dialling a telephone number, but the decision 'on the spot' to perform that act as well. Yet, this fragment cannot be classified as a case of speech act causality (cf. Sweetser, 1990) since neither making a phone call nor the decision to perform the act of making a phone call are speech acts. The fragment cannot be classified as epistemic causality either, because the specific wording does not only convey an evaluation, but can only be used if the speaker is about to perform the action. 
interpretation of volitional causal relations is that the situation presented as the 'cause' falls within the domain of the actor who interprets this situation as a reason for performing the action that functions as the causal relation's effect (Pander Maat, Degand, 2001; see also Pander Maat, Sanders, 2000). We do not adopt the assumption that volitional causal relations are inherently subjective (cf. our discussion in section 2), but we want to explore the idea that this characteristic of 'default continuous actor perspective' in the way volitional causality is constructed in reality, has consequences for the interpretation of cases we classified as 'neutral-character' in table 1. If the SOC of the causal relation is construed subjectively (in which case the effect segment of the causal relation is classified as 'character perspective') it is likely that the SOC's perspective is 'carried over' to the cause segment of the causal relation. As an example, consider [21].

[21] Beide evenementen zijn niet alleen naar Rotterdam gegaan, ze zijn ook gehaald. In de Maasstad ondervinden ze de warme steun van de Stichting Rotterdam Topsport. ["Het is bewust beleid evenementen naar Rotterdam, City of Sports, te halen"] directeur Hans den Oudendammer. En $\underline{\text { dus }}$ [sloeg de stichting alert toe $]_{\mathrm{E}}$.

'Both events not only have gone to Rotterdam, they were brought over as well. In the City of the Maas river they find warm support of the Foundation Rotterdam Top sport. ["Getting events to Rotterdam, City of Sports, has been intentional policy,] " director Hans den Oudendammer says. And "dus" [the foundation attentively jumped to the occasion.] $]_{\mathrm{E}}$ '.

61 The objective state of affairs that it is bewust beleid evenementen naar Rotterdam, the City of Sports, te halen 'Getting events to Rotterdam, City of Sports, has been intentional policy' functions as the cause segment of the relation. The effect segment is subjectified with the subjective element alert 'attentively', reporting a 'state of consciousness' that is to be attributed to de stichting 'the foundation'. It is only very likely that the objective situation functioning as the cause was part of the SOC's perspective at the moment that they decided to perform the action of toeslaan 'jump to the occasion'. Therefore, we assume that the cases in the cell 'neutral-character' of table 1 have continuous character perspective carrier by way of 'percolation' (Spooren, Jaspers, 1990) of the SOC's perspective to the cause segment21.

62 This yields the distribution of $d u s$ and daarom over perspective carrier types reported in table 2. The differences in distribution over 'perspective carrier' and 'neutral perspective' are statistically significant $(\mathrm{Z}=2.388 ; \mathrm{p}<.05) 22$.

Table 2 Perspective configurations construed from the effect segment.

\begin{tabular}{llll}
\hline & Daarom & Dus & Total \\
\hline Author & 0 & 1 & 1 \\
Character & 6 & 12 & 18 \\
Neutral & 16 & 7 & 23 \\
Ambiguous & 1 & 3 & 4 \\
\hline Total & 23 & 23 & 46 \\
\hline
\end{tabular}

63 Although our analysis of perspective carrier so far is explorative, this finding suggests that our model of analysis is able to capture differences between volitional causal daarom and

\footnotetext{
${ }^{21}$ Evidently, a similar line of argumentation holds for the cell 'neutral-author', but as our sample did not contain any cases of this configuration, we do not discuss it.

${ }^{22}$ The cells 'perspective carrier: character' and 'perspective carrier: author' (containing only one, and probably rare, case of a 'performative' volitional causal relation, discussed as (20)) were combined into one category 'perspective carrier'. Occurrence of $d u s$ and daarom over this category was compared with the occurrence in the cell 'neutral perspective'. Fragments that were ambiguous with respect to perspective carrier were not taken into account.
} 
dus. The distribution over perspective types in the sample analyzed yielded by our model of analysis corroborate previous findings (Pander Maat, Sanders, 2000; Degand, Pander Maat, 2003) in that volitional causal relations marked with $d u s$ are construed from a subjective perspective, or: contain a perspective carrier, more often than volitional causal relations marked with daarom. More precisely, daarom has a preference for objective volitional causal relations which is lacking in dus. This finding suggests that if a volitional causal relation is to be construed from a subjective perspective, dus is the preferred option for marking the causal relation. In these cases, the causal relation's SOC counts as the perspective carrier. Clear examples of this pattern are fragments [13], [14] and [15] discussed above. This is the type of subjectivity in volitional causal relations that has been discussed in previous studies.

64 We saw, however, that perspective configurations may be more complex. For example, next to the relation's SOC, the author of the text may be construed as an additional perspective carrier. As an example of this pattern, we discussed [18], repeated here as [22]:

[22] Schreijer vond dat er hoognodig een boerin in de Kamer moest komen, en dus is zij met zelfgemaakte worst en kaas op markten gaan staan.

'Schreijer felt it highly necessary to have a peasant woman in the House of Commons, and "dus" she went to the market to sell homemade sausage and cheese'.

65 Since both the cause segment and the effect segment are ambiguous with respect to source of the subjective perspective, we assume that the relation as a whole is ambiguous for perspective carrier. Another type of ambiguity we found concerns a blend of different character perspective carriers in the text. We discussed [17] (repeated as [23]) as an example of this pattern. Again, both the cause and the effect segment are ambiguous with respect to source of the subjective perspective: Theo Nijland, or his brother.

[23] (Interview with 'multi talent' Theo Nijland.) [Zijn broer besloot dat het tijd was om echt door te breken.] "Je liedjes zijn zó prachtig; waarom zitten er dan maar zo weinig mensen in de zaal?" En eigenlijk irriteerde Theo Nijland [46] zich er zelf ook aan dat 'de machine niet goed liep'. Dus [zei broer Wout zijn baan op als pr-man bij de PvdA en ging hij de barricaden op om Theo te promoten. $]_{\mathrm{E}}$

'[His brother decided that it was time to break through 'for real'. $]_{\mathrm{C}}$ "Your songs are so beautiful; why is it that there is only a small audience at concerts? And as a matter of fact, Theo Nijland [46] himself was annoyed too by the fact that 'the engine didn't run well'. "Dus" [brother Wout quit his job as a PR manager with the PvdA (a Dutch political party) and he stood on the barricades with the aim of promoting Theo. $]_{\mathrm{E}}$ '

66 Cases like [22] and [23] were classified as 'ambiguous' in table 2. Hypothetically, ambiguity of perspective at the level of the causal relation may also occur when the cause segment has a source of subjectivity that differs from the source in the effect segment. We did not find examples of this pattern in our sample. Finally, we assume that volitional causal relations may be construed objectively as well. This is the case if the causal relation does not contain any subjectivity indicators at all (cf. discussion in section 5); an example is fragment [12].

\section{Discussion}

67 In this study, we investigated the linguistic categorization hypothesis for a specific type of causal connectives: those expressing forward causality in Dutch. Despite the fact that earlier corpus studies have shown that the forward causal connectives used most frequently in Dutch - daardoor, daarom, and dus - have a clear, statistically significant, preference for one specific causal category, each one of the connectives is also used to express "another connective's prototypical meaning". Although the frequency of occurrence of these nonprototypical usage events vary among connectives (daardoor is almost exclusively used in non-volitional causal relations, while dus and daarom are much more flexible with respect 
to contexts of use, cf. section 2), it is beyond questioning that there is no black and white difference between categories of meaning and use. How can we explain for these results? Should this observation be taken as counterevidence against a linguistic categorization hypothesis? These are the questions inspiring our further investigation. In this paper, we focused on a specific example of variation: the fact that volitional causal relations (prototypically associated with daarom) is also marked with $d u s$ (which prototypically used in epistemic causal relations).

68 The main aim of our study was to contribute to a more complete understanding of how subjective perspective is linguistically construed in volitional causal relations. We have advanced on previous studies, which had concluded that volitional causal relations marked with $d u s$ are more subjective than volitional causal relations marked with daarom. We believe that the pattern of alternating marking options of a specific causal relation as reported here, is only one specific example of a more widely occurring pattern: causality markers of different grammatical type tend to specialize in one specific conceptual category of causality, but may be used in different contexts as well. Similar patterns are found with causal verbs (Verhagen, Kemmer, 1997; Verhagen, 2000; Stukker et al., 2008) which suggest that variation in usage patterns of causal verbs and causal connectives are caused by similar mechanisms. Our ultimate goal is to understand why variation in marking patterns of one and the same type of causal coherence relation occurs. In this paper, we propose as an explanation: the usage-based categorization hypothesis. We follow usage-based theories of language which assume that variation is an inherent characteristic of language use, and seek to explain patterns of variation with reference to more general cognitive mechanisms (e.g. Langacker, 1987; Bybee, 2006; 2007; contributions to Barlow, Kemmer, 2000). We propose that an interplay of conceptual and usage factors can explain why the use of Dutch causal connectives does not always conform to abstract definitions that seem to be quite straightforward otherwise. Our usage-based categorization hypothesis predicts that 'deviant' contexts of use are in fact non-prototypical members of the same semantic category that is more directly reflected in the connective's prototypical contexts of use. We analyze nonprototypical usage (NPU) events as purposeful rhetorical construals (Stukker et al., 2008; submitted), 'blending' the actual causality type expressed in the causal coherence relation with the causality type prototypically associated with the connective which marks the causal relation (Sanders et al., submitted).

69 A crucial assumption underlying our usage-based categorization hypothesis (and in fact any linguistic theory on categorization) is that the causality categories we discussed are conceptually distinct and clearly delineated categories. We assume that volitional causality and epistemic causality - the categories daarom and $d u s$ are respectively prototypically associated with - differ in terms of subjectivity. We have argued that subjectivity is an inherent characteristic of epistemic causality, while volitional causality is inherently objective. Still, the actor SOC in volitional causal relations opens the possibility to construe subjectivity in volitional causal contexts (cf. section 2). The assumption that epistemic causality is more subjective than volitional causality is uncontroversial, but the idea that epistemic causality and volitional causality are conceptually distinct categories is not generally endorsed (see discussion in section 2). Previous studies of causal connectives have suggested that their meaning must be characterized as positions on a scale of subjectivity rather than as conceptually distinct categories (cf. Pander Maat, Degand, 2001; Pit, 2003). The ground for proposing a scalar notion of subjectivity and for dismissing the linguistic categorization hypothesis, was exactly the need to account for the variability observed in connective usages. The usage-based categorization hypothesis we propose here, makes it possible to accommodate for this variability within the assumed categorization function of connectives. As a matter of fact, NPU are analyzed as a natural consequence of the assumed categorization function of connectives. Our explanation in terms of subjective construal implies that the function of NPU is exactly to communicate that in the interpretation of the causal relation, in addition to the causality type which can be inferred from the relation's 
segments, another causal category is relevant - the category which is prototypically associated with the connective used to mark the causal relation (see Stukker et al. (submitted) for a more elaborate argument). In order to increase our understanding of volitional causality in relation to subjectivity, we will undertake further detailed analyses of the contexts of use of causal connectives - using the analytic model presented in this study.

70 This model of analysis aims to characterize patterns of subjectivity and perspective in volitional causal relations in more detail than has been possible before. This linguistic marker of subjectivity in discourse model differs from previous models in several respects. First, multiple operationalizations of the notions of subjectivity and perspective help detect a larger variety of patterns of use, including various patterns of ambiguity. Second, our model acknowledges the fact that accounts of subjectivity and perspective in linguistic theory mostly focus on the clause-level of the linguistic structure, while our object of study concerns the relation between clauses, which is located at the discourse level. Therefore, we designed a model which allows us to analyze the construal of perspective at different levels of complexity. It analyzes linguistic signals of perspectivization that occur within clauses (linguistic reference to the causal relation's SOC, subjective expressions, deictic expressions, tense, embedding) at the level of the clause as a whole (representation mode) and at the level of the causal relation between clauses (the relation's perspective carrier). By explicitly separating the clause level from the discourse level of analysis, we aim to contribute to a better understanding of how relational perspective is derived from various levels in the linguistic structure. Third, it introduces the concept of perspective carrier, which enables us to systematically describe the perspective from which the causal relation is construed.

71 Our model of analysis was applied to a small sample of newspaper texts. We contrasted volitional causal relations marked with daarom with volitional causal relations marked with dus. We investigated the hypothesis (derived from previous studies) that the contexts of NPU volitional dus differ systematically from PU volitional daarom with respect subjective perspective. More specifically, we expect NPU volitional dus to show conceptual relatedness to $d u s$ ' PU epistemic causality. Our findings indicate that volitional causal relations marked with dus, more often than volitional causal relations marked with daarom, are construed from a subjective perspective; that is, they contain a perspective carrier usually the author or the relation's SOC, more often. More precisely, unlike dus-cases, instances of daarom show a preference for objective volitional causal relations. This finding suggests that if a volitional causal relation is to be construed from a subjective perspective, $d u s$ is the preferred option for marking the causal relation.

72 Hence, a clear result of our analysis is that it is the relational level that is relevant for characterizing differences between dus and daarom-marked volitional causal relations. The 'relational' variable perspective carrier is the only one that adequately describes differences between volitional dus and daarom in our sample. This is an important finding, since this variable yields the sum and interpretation of all other 'lower level' variables. In view of the function of causal connectives as markers of causal coherence relations, this finding need not surprise us. Interestingly, none of the 'intra-segment' and 'segment' variables turned out to characterize the difference between dus and daarom. Similar findings are reported by Pit (2003), who does not find differences between the backward causal connectives doordat, omdat and want with respect to tense of the segments and subjective elements. We found that patterns for the variable tense in our sample do not conform to expectations (Fleischman, 1990; Pit, 2003: 150-1). We expect that an analysis that takes communicative context into account will allow us to evaluate our hypothesis that conventions of use for grammatical tense are influenced by communicative context (cf. section 4.1). An important additional question is: how do variables correlate? Are they multiple, independently reliable indicators of differences in subjectivity and perspective, or do interactions occur? The latter option is suggested by Pit (2003: 186-192) who finds that representation mode only yields 
significant differences in interaction with other variables, such as SOC reference 23. Although the contrast between dus and daarom in volitional causal relations is in line with our hypothesis, the exact nature of this difference is somewhat different from what we expected. Our usage-based categorization hypothesis predicts that NPU volitional $d u s$ is restricted to contexts in which subjectivity is a relevant element in the interpretation of the causal relation; it cannot construe subjectivity 'on its own'. In other words: a subjective interpretation of the causal relation needs to be congruent with at least one other element in the communicative context. Therefore, we had expected to find that PU volitional daarom is the unmarked option for marking volitional causal relations, and that NPU volitional $d u s$ occurs in contexts that are rhetorically 'marked' for subjectivity. However, what we did find was that daarom has a statistically significant preference for objectively construed volitional causal relation, while dus seems to be distributed over subjective and objective volitional causal relations more or less evenly. This apparent discrepancy between predictions and results will be investigated in future research.

73 We expect to solve these and other remaining issues in further corpus-analytical research. We obviously need to extend the pilot analysis presented here in both a quantitative and qualitative respect. As to the first issue, more similar corpus analyses of several discourse genres are currently under way. As for the second matter, in order to ensure a maximally reliable method, the qualitative analysis of overt linguistic markers of subjectivity remains at the heart of our approach. However, the linguistic analysis of subjectivity will be extended to larger discourse contexts. Given our analysis of NPU in terms of subjective construals (cf. section 2), we expect that rhetorical motivations authors may have for using a non-prototypical connective as a marker for a causal coherence relation may not only become apparent from the immediate local context of the segments related by the connective (which was analyzed in the present paper), but also from the more global context of the discourse as a whole (cf. Verhagen, Kemmer, 1997; Verhagen, 2000 on causal verbs). We intend to include the rhetorical purposes of the author and the conventional communicative goal of a text type the causal relation occurs in. Such an analysis remains true to the 'linguistic markers of subjecivity' approach, while acknowledging the insight that language use is inherently underspecified (cf. Fauconnier, 1985; Sperber, Wilson, 1995; Verhagen, 1997; Langacker, 1987; 2000, and many others).

74 Finally, we should address an additional methodological issue. The pilot study reported in this paper addressed the relation between linguistic categories and conceptual categories only from the semasiological perspective: given the forms, what do they express? For a complete understanding of the relation between causal connectives and conceptual categories of causality, we need to address the issue from the opposite perspective as well. Our usage-based categorization hypothesis not only predicts the kind of relations between PU and NPU as discussed so far, it specifically also predicts that a particular type of concept, say volitional causality, will typically, and most frequently, be expressed by the associated form. This onomasiological question (cf. Geeraerts et al., 1994; Geeraerts, 1997) will be taken into account in future research24. In conclusion, this paper contributes to the precise linguistic analyses we need in order to get a grip on subjectivity and perspective in the meaning and use of causal connectives. We believe that the further development of such analyses and the application to corpora of spoken and written discourse in various languages will give rise to a well-developed and empirically solid categorization approach to causal connectives, which reveals the regularities in the system and use of these connectives in various languages.

\footnotetext{
${ }^{23}$ Pit's (2003) model of analysis contains the variable 'nature of the causally primary participant' which is highly comparable to our variable 'linguistic reference to the SOC' (Pit, 2003: 123-7).

${ }^{24}$ Findings of a pilot study of cross-genre differences Stukker (2008) suggest that both in news reports and in opinion pieces, volitional causality is prototypically expressed with daarom.
} 


\section{Acknowledgements}

We thank three anonymous reviewers for their useful comments on an earlier version of this paper. All remaining errors are our own. The research presented in this paper was enabled by The Netherlands Organization of Scientific Research, NWO, through NWO-Vici grant 277-70 003, awarded to Ted Sanders.

\section{REFERENCES}

ARIEL, M. (1990). Accessing Noun Phrase antecedents. London, Routledge.

ASHER, N., LASCARIDES, A. (1998). Bridging. Journal of Semantics 15: 83-113.

BANFIELD, A. (1982). Unspeakable sentences. Narration and representation in the language of fiction. Boston: Routledge.

Barlow, M., Kemmer, S. (eds.) (2000). Usage based models of language. Stanford, CSLI Publications.

BIBER, D., FINEGAN, E. (1989). Styles of stance in English: Lexical and grammatical marking of evidentiality and affect. Text 9: 93-124.

BYBEE, J. (1985). Morphology: a study of the relation between meaning and form. Amsterdam, John Benjamins.

ByBEE, J. (2006). From usage to grammar: The mind's response to repetition. Language 82: 711733.

BYBEe, J. (2007). Frequency of use and the organization of language. Oxford, Oxford University Press.

D'ANDRADE, R. (1987). A folk model of the mind. In: D. Holland \& N. QuinN (eds.) Cultural models in language and thought. Cambridge, Cambridge University Press, 112-148.

Degand, L., Pander MaAt, H. (2003). A contrastive study of Dutch and French causal connectives on the Speaker Involvement Scale. In A. VERHAGEN \& J. VAN DE WEIJER, eds., Usage based approaches to Dutch, Utrecht, LOT, 175-199.

DELANCEY, S. (1984). Notes on agentivity and causation. Studies in language 8 (2): 181-213.

De SMET, H., Verstraete J.-C. (2006). Coming to terms with subjectivity. Cognitive Linguistics 17. 365-392.

Doron, E. (1990). Point of view. CSLI paper nr. 90-143. Stanford: Leland Stanford Junior University.

DuCrot, O. (1983). Puisque: essai de decription polyphonique. I. Revue Romaine: 24, 166-185.

Evers-Vermeul, J., StukKer N. (2003). Subjectificatie in de ontwikkeling van causale connectieven? De diachronie van daarom, dus, want en omdat. Gramma/TTT 9 (2,3): 111-139.

FAUCONNIER, G. (1985). Mental Spaces. Cambridge MA, MIT Press. (Reprinted 1994, Cambridge: Cambridge University Press).

FAUCONNIER, G., TURNER, M. (2002). The way we think: Conceptual blending and the mind's hidden complexities. New York, Basic Books.

FINEGAN, E. (1995). Subjectivity and subjectivisation: an introduction. In: D. STEIN \& S. WRIGHT (eds.) Subjectivity and subjectivisation. Cambridge, Cambridge University Press: 1-15.

Fleischman, S. (1990). Tense and narrativity. From medieval performance to modern fiction. Austin, University of Texas Press.

FroHnING, D. (2007). Kausalmarker zwischen Pragmatik und Kognition. Korpusbasierte Analysen zur Variation im Deutschen. Tuebingen, Niemeyer.

GEERAERTS, D. (1997). Diachronic prototype semantics. A contribution to historical lexicology. Oxford, Clarendon Press. 
Geeraerts, D., Grondelaers, S., Bakema, P. (1994). The structure of lexical variation. Meaning naming, and context. Berlin, Mouton de Gruyter.

GOLDBERG, A. (2005). Constructions at work. The nature of generalization in language. Oxford, Oxford University Press

GÜNTHNER, S. (1993). “.... Weil - man kann es ja wissenschaftlich untersuchen” Diskurspragmatische Aspekte der Wortstellung in WEIL-satzen. Linguistische Berichte 143: 3755.

HASHER, L. (1984). Automatic processing of fundamental information: The case of frequency of occurrence. American Psychologist 39: 1372-1388.

HobBS, J.R. (1979). Coherence and coreference. Cognitive science 3: 67-90.

Keller, R. (1995). The epistemic weil. In D. STEIN \& S. Wright (eds.), Subjectivity and subjectivisation: linguistic perspectives. Cambridge, Cambridge University Press: 16-30

KnotT, A., DALE, R. (1994). Using linguistic phenomena to motivate a set of coherence relations. Discourse Processes 18: 35-62.

KnotT, A., SANDERs, T. (1998). The classification of coherence relations and their linguistic markers: An exploration of two languages. Journal of Pragmatics 30: 135-175.

KunO, S. (1987). Functional syntax: Anaphora, discourse and empathy. Chicago, The University of Chicago Press.

LAKOFF, G. (1987). Women, fire and dangerous things. What categories reveal about the mind. Chicago, University of Chicago Press.

LAKOFF, G., JoHnSON, M. (1980). Metaphors we live by. Chicago, University of Chicago Press.

LANGACKER, R.W. (1987). Foundations of cognitive grammar. Vol. I, Theoretical prerequisites. Stanford, Stanford University Press

LANGACKER, R.W. (1990). Subjectification. Cognitive Linguistics 1: 5-38.

LANGACKER, R.W. (2000). A dynamic usage-based model. In M. BARLOW \& S. KEMMER (eds.) Usage based models of language. Stanford, CSLI Publications, 1-63.

LANGACKER, R.W. (2002, [1990]) Concept, image, and symbol. The cognitive basis of grammar. Berlin, Mouton de Gruyter.

LASCARIDES, A., ASHER, N. (1993). Temporal interpretation, discourse relations and commonsense entailment. Linguistics and Philosophy 16: 437-493.

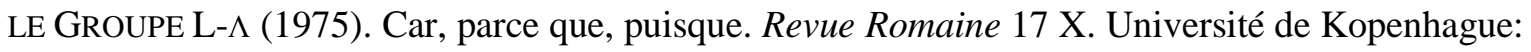
249-280.

LyONS, J. (1995). Linguistic semantics. An introduction. Cambridge, Cambridge University Press.

MANN, W.C., THOMPSON, S.A. (1988). Rhetorical structure theory: towards a functional theory of text organization. Text 8: 243-281.

Martin, J.R. (1992). English text: system and structure. Philadelphia, John Benjamins.

OVERSTEEGEN, E.E. (2005). Causality and tense - two temporal structure builders. Journal of semantics 22: 307-337.

Pander MaAt, H., Degand, L. (2001). Scaling causal relations and connectives in terms of speaker involvement. Cognitive Linguistics 12: 211-245.

PANDER MAAT, H., SANDERS, T. (1995). Nederlandse causale connectieven en het onderscheid tussen inhoudelijke en epistemische relaties ("Dutch causal connectives and the distinction between content and epistemic relations"). Leuvense Bijdragen 3: 349-374.

PANDER MaAt, H., SANDERS, T. (2000). Domains of use or subjectivity: The distribution of three Dutch causal connectives explained. In E. COUPER-KuHLEN \& B. KortMAnN (eds.) Cause, 
condition, concession, and contrast: Cognitive and discourse perspectives. Berlin, Mouton de Gruyter, 57-82.

PANDER MAAT, H., SANDERS, T. (2001). Subjectivity in causal connectives: An empirical study of language in use. Cognitive linguistics 12-3: 247-273.

PASCH, R. (1983). Die Kausalkonjunktionen 'da', 'denn', und 'weil': drei Konjunktionen, drei Lexicale Klassen. Deutsch als Fremdsprache 20: 332-337.

PIT, M. (2003). How to express yourself with a causal connective? Subjectivity and causal connectives in Dutch, German and French. Dissertation Utrecht University. Amsterdam: Rodopi.

Rosch, E. (1973). Natural categories. Cognitive Psychology 4: 328-350.

RosCH, E., MERVIS, C. (1975). Family resemblances: studies in the internal structure of categories. Cognitive Psychology 7: 573-605.

SANDERS, J.M. (1994). Perspective in narrative discourse. Dissertation Katholieke Universiteit Brabant.

SANDERS, J., SPOOREN, W. (1997). Perspective, subjectivity, and modality from a cognitive linguistic point of view. In W. LIEBERT, G. REDEKER \& L. WAUGH (eds.) Discourse and perspective in cognitive linguistics. Amsterdam, John Benjamins, 85-112.

SANDERS, J., ReDEKER, G. (1996). Perspective and the representation of speech and thought in narrative discourse. In G. FAUCONNIER \& E. SWEETSER (eds.) Spaces, worlds and grammars. Chicago, University of Chicago Press, 290-317.

SANDERS, T. (1997). Semantic and pragmatic sources of coherence: on the categorization of coherence relations in context. Discourse Processes 24: 119-147.

SANDERS, T., SANDERS, J., SwEETSER, E. (submitted). Causality, cognition and communication: A mental space analysis of subjectivity in causal connectives.

SANDERS, T., SpoOREN, W. (submitted), Causal categories in discourse - Converging evidence from language use.

SANDERS, T., SPOOREN, W., NOORDMAN, L. (1993). Coherence relations in a cognitive theory of discourse representation. Cognitive Linguistics 4: 93-133.

SCHMID, H.-J. (2000). English abstract nouns as conceptual shells. From corpus to cognition. Berlin, Mouton de Gruyter.

SPerber, D., Wilson, D. (1995). Relevance. Communication \& cognition. Oxford, Blackwell.

SPOOREN, W., JASPERS, J. (1990). Tekstoperaties en tekstperspectieven. Gramma/TTT 14: 195220.

Spooren, W., SANDERs, T., Huiskes, M., Degand, L. (in press). Subjectivity and Causality: A Corpus Study of Spoken Language. In J. Newman \& S. RICE (eds). Conceptual Structure in Discourse and Language.

STUKKER, N. (2005). Causality marking across levels of language structure. A cognitive semantic analysis of causal verbs and causal connectives in Dutch. Dissertation Utrecht University, Utrecht: LOT.

STUKKER, N. (2008).Variatie in causaal connectiefgebruik in verschillende soorten teksten: een usage-based benadering ("Variation in causal connective use across text types: a usage-based approach"). Paper presented at Vereniging Interuniversitair Overleg Taalbeheersing (VIOT) conference, Amsterdam: Vrije Universiteit.

StukKer, N., SANDERs, T., Verhagen A. (2008). Causality in verbs and in discourse connectives. Converging evidence of cross-level parallels in Dutch linguistic categorization. Journal of Pragmatics 40: 1296-1322.

StUKKer, N., SANDERS, T., Verhagen A. (submitted). Categories of subjectivity in Dutch causal connectives: a usage-based analysis. 
SWEETSER, E.E. (1990) From etymology to pragmatics. Cambridge, Cambridge University Press. SweEtSER, E., FAUCONNIER, G. (1996). Cognitive links and domains: Basic aspects of mental space theory. In G. FAUCONNIER \& E. SwEETSER (eds.) Spaces, worlds and grammars. Chicago, University of Chicago Press, 1-28.

TALMY, L. (1988). Force dynamics in language and cognition. Cognitive Science 12: 49-100.

TALMY, L. (2000). Toward a cognitive semantics. Vol I Cambridge, London, MIT Press.

TRAUGOTT, E.C. (1989). On the rise of epistemic meanings in English: an example of subjectification in semantic change. Language 57: 33-65

TraugotT, E.C. (1995). Subjectification in grammaticalization. In D. STEIN \& S. Wright, eds., Subjectivity and subjectivisation: Linguistic perspective. Cambridge, Cambridge University Press: 31-54.

TURner, M. (1987). Death is the mother of beauty. Chicago, Chicago Press.

VAN DEN BERGH, H. (1989). Examens geëxamineerd. Den Haag: SVO.

VERHAGEN, A. (1997). Context, meaning, and interpretation, in a practical approach to linguistics. In L. LENTZ \& H.L.W. PANDER MAAT (eds.), Discourse analysis and discourse evaluation. Amsterdam, Rodopi: 7-39.

VERHAGEN, A. (2000). Interpreting usage: construing the history of Dutch causal verbs. In M. BARLOW \& S. KEMMER (eds) Usage based models of language. Stanford, CSLI Publications, 261286.

Verhagen, A. (2005). Constructions of intersubjectivity. Discourse, syntax, and cognition. Oxford, Oxford University Press.

Verhagen, A. (2007). Construal and perspectivization. In D. GEeRAERTS \& H. CuYCKENS (eds.) Handbook of cognitive linguistics. Oxford: Oxford University Press, 48-81.

VERHAGEN, A., KEMMER, S. (1997). Interaction and causation: causative constructions in modern standard Dutch. Journal of Pragmatics 27: 61-82.

Wittgenstein, L. (1958). Philosophical investigations, transl. by G.E.M. Anscobe. Oxford, Blackwell.

ZUFFEREY, S. (2007). Pragmatique lexicale et métareprésentation: Étude théorique et empirique de l'utilisation et de l'acquisition des connecteurs pragmatiques. $\mathrm{PhD}$ thesis, University of Geneva. 


\section{APPENDIX}

Figure A1. Linguistic variables used to determine perspective and subjectivity in causal coherence relations.

\begin{tabular}{|c|c|c|}
\hline Variable & Values (subjective... objective) & Level \\
\hline 1. Embedding & $\begin{array}{l}\text { Mertal state complement construction; embedding } \\
\text { predicate; quotation marks; absent. }\end{array}$ & $\begin{array}{c}\text { Below clause } \\
\downarrow\end{array}$ \\
\hline 2. SOC reference & $\begin{array}{l}\text { Implicit author SOC, } 1^{\text {th }} \text { person pronorninal; } 2^{\text {nl }} \text { pers. } \\
\text { pronorinal; } 3^{\text {rl }} \text { pers. pronominal; } 3^{\text {rl }} \text { pers. nominal; } \\
\text { unspecified; absent. }\end{array}$ & \\
\hline $\begin{array}{l}\text { 3. Subjective } \\
\text { elements }\end{array}$ & Author (ground); character ; unrmarked. & $\downarrow$ \\
\hline 4. Deictic elements & Author (ground); character; unmarked. & \\
\hline 5. Tense & $\begin{array}{l}\text { Future; simple presert; presert perfect; simple past; } \\
\text { past perfect. }\end{array}$ & \\
\hline $\begin{array}{l}\text { 6.Representation } \\
\text { mode }\end{array}$ & $\begin{array}{l}\text { Subjective author discourse; subjective direct mode; } \\
\text { free indirect mode; indirect mode; report (+ implicit } \\
\text { perspective); report (- irmplicit perspective); objective } \\
\text { writer discourse; neutral discourse }\end{array}$ & $\begin{array}{c}\text { Clause } \\
\downarrow\end{array}$ \\
\hline $\begin{array}{l}\text { 7. Perspective } \\
\text { camier }\end{array}$ & Author, character, neutral. & $\begin{array}{l}\text { Relation } \\
\text { between } \\
\text { clauses }\end{array}$ \\
\hline
\end{tabular}

\section{Overview of the distribution of daarom and dus over categories within variables}

1. Linguistic embedding of perspective

Table A1 Embedding type $\mathbf{P}$

\begin{tabular}{l|l|l|l}
\hline & Daarom P & Dus P & Total \\
\hline Mental state CTP & 2 & 4 & 6 \\
Emb predicate & 0 & 2 & 2 \\
Quotes & 10 & 10 & 20 \\
Absent & 11 & 7 & 18 \\
Ambiguous & 0 & 0 & 0 \\
\hline Total & 23 & 23 & 46 \\
\hline
\end{tabular}

\section{Table A2 Embedding type Q}

\begin{tabular}{l|l|l|l}
\hline & Daarom Q & Dus Q & Total \\
\hline Mental state CTP & 0 & 0 & 0 \\
Emb predicate & 0 & 0 & 0 \\
Quotes & 8 & 9 & 17 \\
Absent & 15 & 14 & 29 \\
Ambiguous & 0 & 0 & 0 \\
\hline Total & 23 & 23 & 46 \\
\hline
\end{tabular}


2. Linguistic reference to the SOC

Table A3 Linguistic reference to the SOC of the causal relation

\begin{tabular}{l|l|l|l}
\hline & Daarom & Dus & Total \\
\hline Imp speaker & 0 & 1 & 1 \\
1stp pronon & 7 & 7 & 14 \\
2ndp pronon & 0 & 0 & 0 \\
3rdp pronon & 4 & 5 & 9 \\
3rdp nom & 5 & 5 & 10 \\
Unspec & 6 & 5 & 11 \\
No SOC & 0 & 0 & 0 \\
D.n.a & 1 & 0 & 1 \\
Ambiguous & 0 & 0 & 0 \\
\hline Total & 23 & 23 & 46 \\
\hline
\end{tabular}

3. Subjective elements

Table A4 Subjective elements in P

\begin{tabular}{l|l|l|l}
\hline & Daarom & Dus & Total \\
\hline Author (ground) & 4 & 9 & 13 \\
Character & 6 & 5 & 11 \\
unmarked & 11 & 7 & 18 \\
Ambiguous & 2 & 2 & 4 \\
\hline Total & 23 & 23 & 46 \\
\hline
\end{tabular}

Table A5 Subjective elements in Q

\begin{tabular}{l|l|l|l}
\hline & Daarom & Dus & Total \\
\hline Author (ground) & 0 & 2 & 2 \\
Character & 1 & 2 & 3 \\
unmarked & 22 & 17 & 39 \\
Ambiguous & 0 & 2 & 2 \\
\hline Total & 23 & 23 & 46 \\
\hline
\end{tabular}

4. Deictic elements

$\underline{\text { Table A6 Deictic elements in } \mathbf{P}}$

\begin{tabular}{l|l|l|l}
\hline & Daarom & Dus & Total \\
\hline Author (ground) & 2 & 7 & 9 \\
Character & 4 & 4 & 8 \\
unmarked & 17 & 12 & 29 \\
Ambiguous & 0 & 0 & 0 \\
\hline Total & 23 & 23 & 46 \\
\hline
\end{tabular}


Table A7 Deictic elements in Q

\begin{tabular}{l|l|l|l}
\hline & Daarom & Dus & Total \\
\hline Author (ground) & 1 & 3 & 4 \\
Character & 4 & 1 & 5 \\
unmarked & 18 & 19 & 37 \\
Ambiguous & 0 & 0 & 0 \\
\hline Total & 23 & 23 & 46 \\
\hline
\end{tabular}

5. Tense

$\underline{\text { Table A8 Tense in P-segment }}$

\begin{tabular}{l|l|l|l}
\hline & Daarom P & Dus P & Total \\
\hline Future & 1 & 0 & 1 \\
Simple present & 11 & 11 & 22 \\
Present perfect & 0 & 2 & 2 \\
Simple past & 8 & 9 & 17 \\
Past perfect & 2 & 0 & 2 \\
D.n.a & 0 & 1 & 1 \\
Ambiguous & 0 & 0 & 0 \\
diverse & 1 & 0 & 1 \\
\hline Total & 23 & 23 & 46 \\
\hline
\end{tabular}

Table A9 Tense in Q-segment

\begin{tabular}{l|l|l|l}
\hline & Daarom Q & Dus Q & Total \\
\hline Future & 0 & 1 & 1 \\
Simple present & 8 & 10 & 18 \\
Present perfect & 8 & 2 & 10 \\
Simple past & 5 & 9 & 14 \\
Past perfect & 2 & 0 & 2 \\
D.n.a & 0 & 1 & 1 \\
Ambiguous & 0 & 0 & 0 \\
diverse & 0 & 0 & 0 \\
\hline Total & 23 & 23 & 46 \\
\hline
\end{tabular}

6. Representation mode

Table A10 Representation modes P-segment

\begin{tabular}{l|l|l|l}
\hline & Daarom P & Dus P & Total \\
\hline Aut-sub & 1 & 5 & 6 \\
Dirsub & 3 & 4 & 7 \\
Frind & 0 & 3 & 3 \\
Ind & 1 & 0 & 1 \\
Rep $+p$ & 9 & 4 & 13 \\
Rep-p & 4 & 3 & 7 \\
Sp-obj & 2 & 0 & 2 \\
Dirob & 0 & 1 & 1 \\
Ambiguous & 3 & 3 & 6 \\
\hline Total & 23 & 23 & 46 \\
\hline
\end{tabular}


$\underline{\text { Table A11 Representation modes Q-segment }}$

\begin{tabular}{l|l|l|l}
\hline & Daarom Q & Dus Q & Total \\
\hline Aut-sub & 0 & 1 & 1 \\
Dirsub & 0 & 0 & 0 \\
Frind & 0 & 1 & 1 \\
Ind & 0 & 0 & 0 \\
Rep $+p$ & 7 & 10 & 17 \\
Rep- $p$ & 14 & 7 & 21 \\
Sp-obj & 1 & 0 & 1 \\
Dirob & 0 & 1 & 1 \\
Ambiguous & 1 & 3 & 4 \\
\hline Total & 23 & 23 & 46 \\
\hline
\end{tabular}

\section{To quote this paper :}

e-reference: Ninke Stukker and Ted Sanders, «Another('s) perspective on subjectivity in causal connectives: a usage-based analysis of volitional causal relations », Discours, $4 \mid 2009$, [En ligne], mis en ligne le 30 juin 2009. URL : http://discours.revues.org/index7260.html. 